\title{
WestVirginiaUniversity
}

THE RESEARCH REPOSITORY @ WVU

Graduate Theses, Dissertations, and Problem Reports

2021

\section{Kindergarten Entry Assessment Practices in Pennsylvania}

Anne Katona Linn Ed.D.

West Virginia University, aklinn@mix.wvu.edu

Follow this and additional works at: https://researchrepository.wvu.edu/etd

Part of the Curriculum and Instruction Commons, Early Childhood Education Commons, Educational Assessment, Evaluation, and Research Commons, Educational Leadership Commons, Educational Methods Commons, Educational Psychology Commons, Elementary and Middle and Secondary Education Administration Commons, Elementary Education Commons, Other Social and Behavioral Sciences Commons, Other Teacher Education and Professional Development Commons, and the PreElementary, Early Childhood, Kindergarten Teacher Education Commons

\section{Recommended Citation}

Linn, Anne Katona Ed.D., "Kindergarten Entry Assessment Practices in Pennsylvania" (2021). Graduate Theses, Dissertations, and Problem Reports. 8150.

https://researchrepository.wvu.edu/etd/8150

This Dissertation is protected by copyright and/or related rights. It has been brought to you by the The Research Repository @ WVU with permission from the rights-holder(s). You are free to use this Dissertation in any way that is permitted by the copyright and related rights legislation that applies to your use. For other uses you must obtain permission from the rights-holder(s) directly, unless additional rights are indicated by a Creative Commons license in the record and/ or on the work itself. This Dissertation has been accepted for inclusion in WVU Graduate Theses, Dissertations, and Problem Reports collection by an authorized administrator of The Research Repository @ WVU. For more information, please contact researchrepository@mail.wvu.edu. 
Kindergarten Entry Assessment Practices in Pennsylvania

Anne Katona Linn

\author{
Doctoral Research Dissertation submitted \\ to the College of Education and Human Services \\ at West Virginia University \\ in partial fulfillment of the requirements for the degree of \\ Doctor of Education (Ed.D.) in \\ Educational Psychology
}

\author{
Amy E. Root, Ph.D. Co-Chair \\ M. Cecil Smith, Ph.D. Co-Chair \\ Kimberly Floyd, Ph.D. \\ Cathy Scutta, OTD, BCBA-D
}

Department of Counseling and Learning Sciences

West Virginia University

\title{
Morgantown, West Virginia 2020
}

Keywords: kindergarten, entry assessment, school transitions, whole child, P-3, early childhood education Copyright 2020 Anne Katona Linn 


\title{
Abstract \\ Kindergarten Entry Assessment Practices in Pennsylvania
}

\begin{abstract}
Anne Katona Linn
In the Commonwealth of Pennsylvania, there is significant variation in kindergarten programs and the entry assessment systems used in school districts. There are no reliable data on the kindergarten entry assessment (KEA) systems used in public kindergarten programs across the Commonwealth. It is well-established that comprehensive KEAs should be part of a broader preschool through third grade (P-3) continuum of early childhood education to assess wholechild skills, include families and community partners, be culturally and linguistically responsive, and developmentally appropriate. This study aimed to understand the KEA practices of kindergarten teachers in Pennsylvania. An online survey was distributed to kindergarten teachers and elementary administrators in K5 classrooms in Pennsylvania public schools. The study evaluated the best practice strategies used including the skill domains assessed, the types of assessment instruments used, the purposes of KEA, and the professional development opportunities for teachers to implement the KEA system implemented by school districts. Responses were analyzed using an independent sample $t$-test to identify differences between groups for ratings of professional development types. There were significant differences between teachers and administrators on professional development teachers received for administering and conducting analyses for KEAs. Further research is needed to identify a larger sample of participants to inform policies and practices for teacher preparation, professional development, and the development of KEA systems in Pennsylvania. The data may also inform best practices for implementation, instructional content and strategies, and early childhood education curricula across the Commonwealth.
\end{abstract}




\section{Acknowledgments}

This dissertation would not have been possible without the support of Cathy Scutta. As my good friend, colleague, and doctoral committee member, she has taught me more than I could ever give her credit for here. She has shown me, by her example, what a leader, a professional (and person) should be. I am especially indebted to Dr. Dan Hursh, who made this doctoral program possible for our cohort of Competent Learner Model (CLM) professionals. You are sorely missed, Dan. I am grateful to Dr. Reagan Curtis and Dr. Neal Shambaugh for stepping in as my Doctoral chairs after Dan's passing to continue this work.

I owe a debt of gratitude to Dr. M. Cecil Smith and Dr. Amy Root, the co-chairmen of my Doctoral Committee, for getting me across the finish line. Each member of my Dissertation Committee, including Dr. Kimberly Floyd, has provided me extensive personal and professional guidance and taught me a great deal about both scientific research and life in general.

I am grateful to all of those I have had the pleasure to work with during this and other related projects, Dr. Kristina Zaccaria, Dr. Cristin Ketley, Dr. Kathryn Poggi, Dr. Lisa Anderson, and the rest of our cohort. Thank you for your support and encouragement. I would especially like to thank Vicci Tucci for starting all this work so many years ago. Her vision, empathy, commitment to excellence, wisdom, humor, and persistence has inspired me to continue to follow my dreams.

Nobody has been more important to me in the pursuit of this project than my family. I want to thank my parents, siblings, and in-laws, whose love and support are with me in whatever I pursue. Most importantly, I wish to thank my loving, resilient, strong, tenacious, and supportive husband, Mark. He has encouraged me and supported me along with our two wonderful children, Sarah and her husband Steven, Nathan \& Janelle, and our granddaughters Emily, Claire, and Sophina who provide unending inspiration and joy. 


\section{Contents}

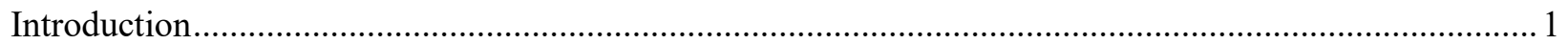

Kindergarten Entry Assessments in Pennsylvania................................................................................ 1

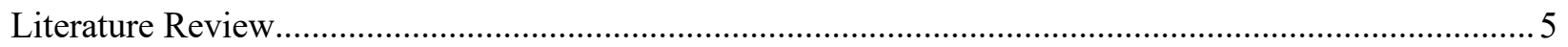

Comprehensive Early Childhood Education/Kindergarten Assessment System .................................. 7

Assessments of Children's Skills, Knowledge, and Behaviors ......................................................... 10

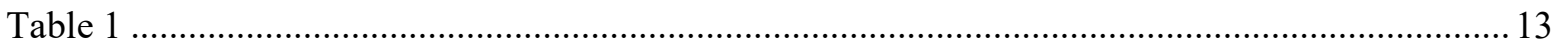

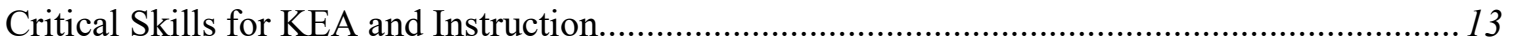

The Kindergarten Entry/School Readiness Debate ............................................................................. 14

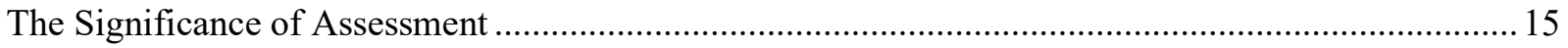

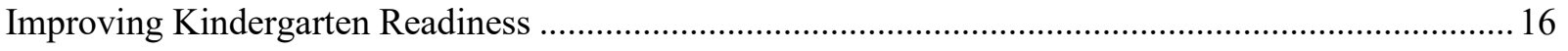

Best Practice Strategies of Kindergarten Entry Assessments ........................................................... 18

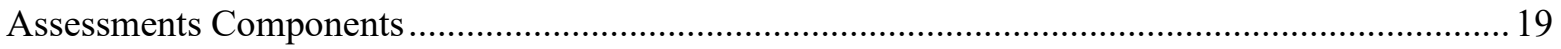

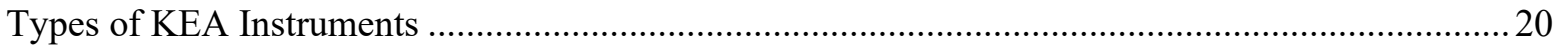

Purposes of KEA

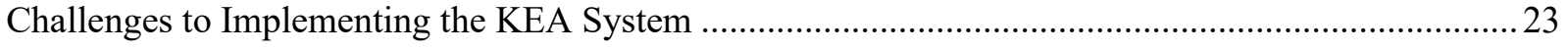

Need for ECE/Kindergarten Teacher Professional Development....................................................... 24

Instructional Coaching to Assist Kindergarten Teachers in Using/Interpreting Assessments ................ 25

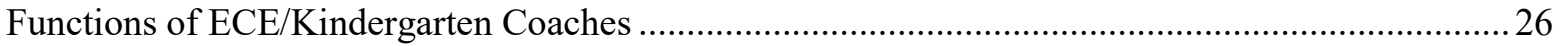

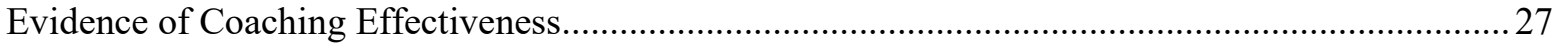

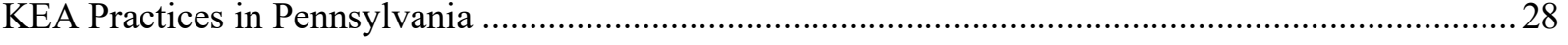

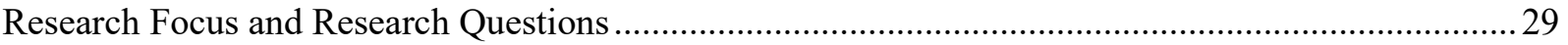

1. What kindergarten entry assessment practices are used by PA kindergarten teachers? ....................29

2. What kinds of professional development and coaching do kindergarten teachers receive to perform

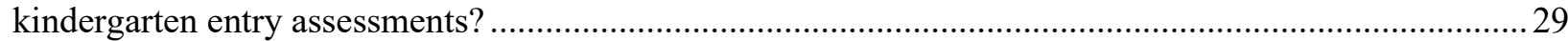

3. Are there differences in teachers' and administrators' knowledge and views of kindergarten entry

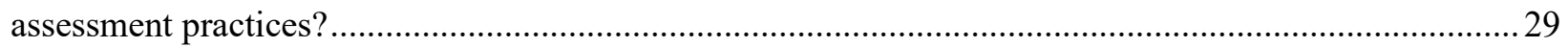

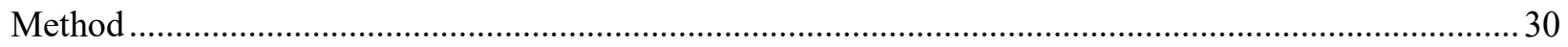

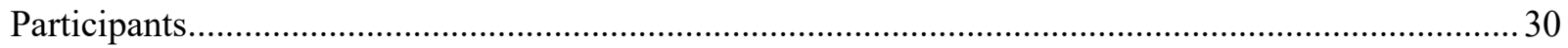

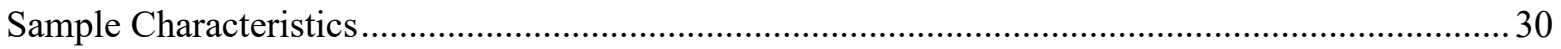

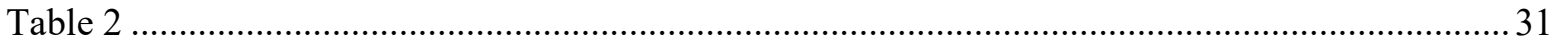

Years Teaching (Teachers) or Supervising (Admin) by Role ..................................................... 31

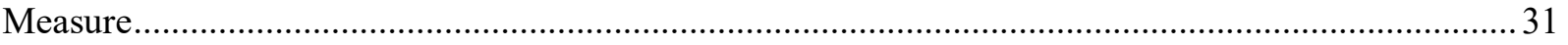

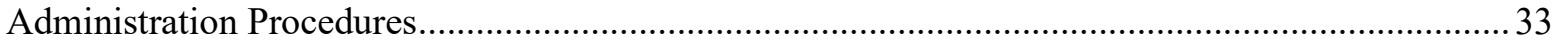




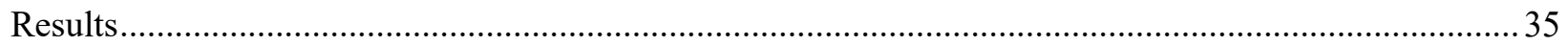

Comprehensive Early Childhood Education/Kindergarten Assessment System ................................. 35

Types of Kindergarten Entry Assessment Instruments used by Teachers ....................................... 35

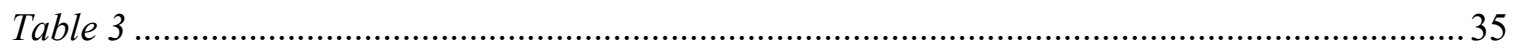

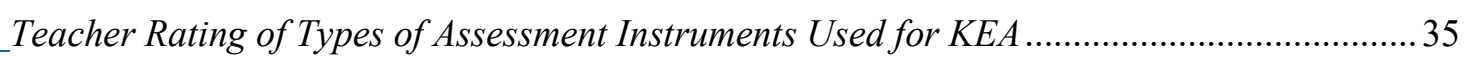

Best Practice Strategies of Kindergarten Entry Assessments ............................................................. 35

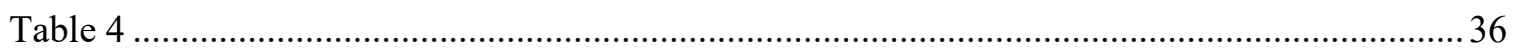

_Teacher Rating of Best Practice Strategies Used for KEA ...................................................... 36

Purposes for Kindergarten Entry Assessments ............................................................................... 36

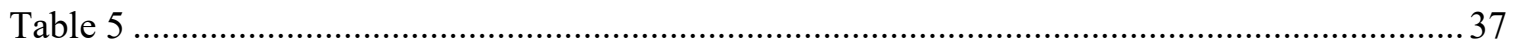

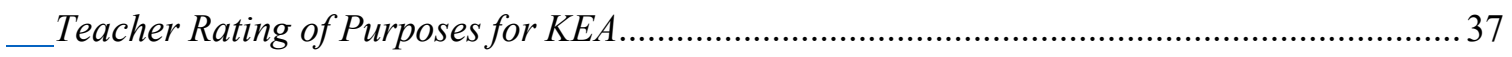

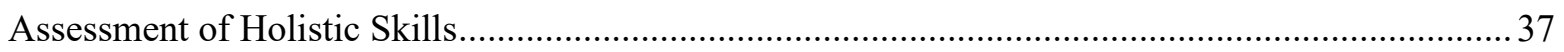

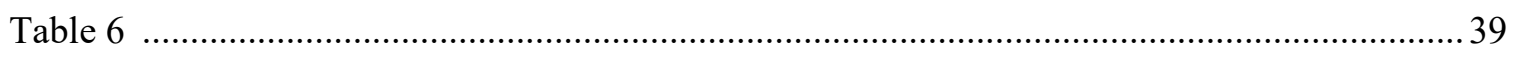

Teacher Rating of Skill Domains Measured by KEA ......................................................... 39

Instructional Coaching to Assist Kindergarten Teachers in Using/Interpreting Assessments ................ 39

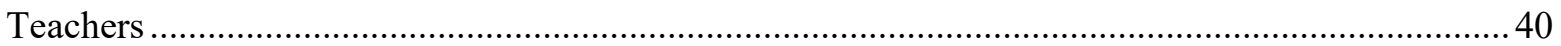

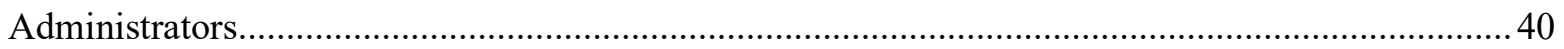

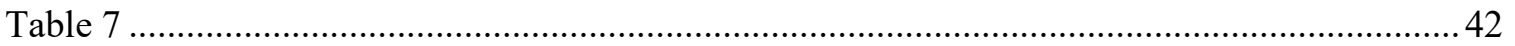

Rating by Group for Types of Professional Development for KEA …................................... 42

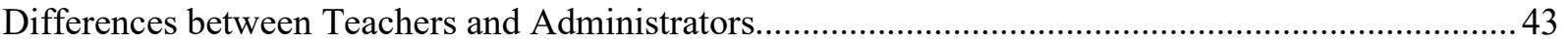

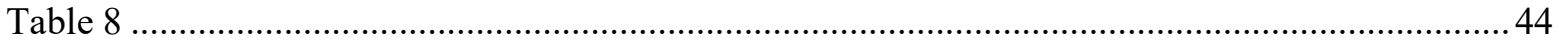

Independent Samples t-Test between Teachers and Administrators on Professional Development 44

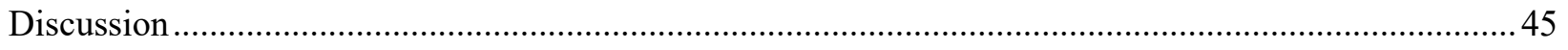

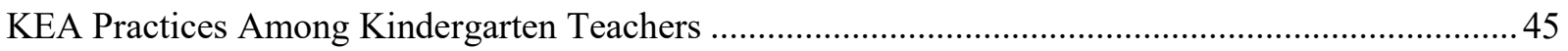

Assessments to Understand Children's Skills, Knowledge, and Behaviors .................................... 46

Kindergarten Assessment Best Practices Strategies ................................................................... 47

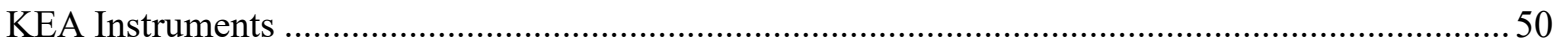

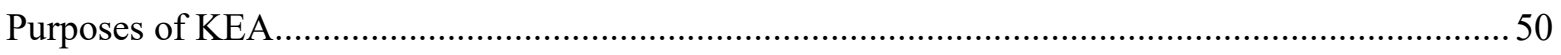

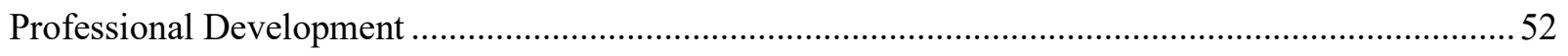

Differences Between Teachers and Administrators Reports .........................................................5 52

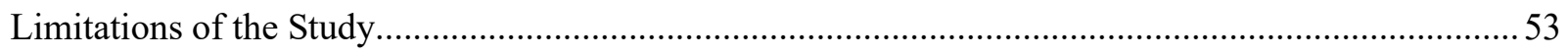

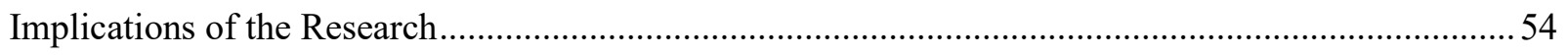

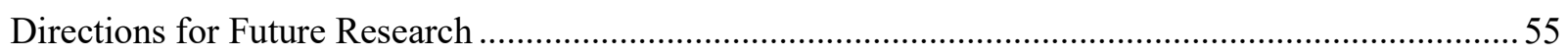

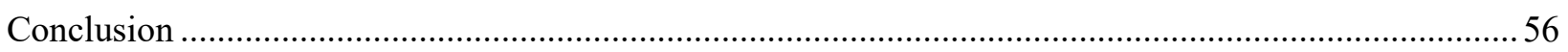




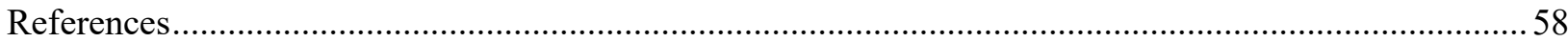

Appendix A. Teacher Survey

Appendix B. Administrator Survey 


\section{Introduction}

\section{Kindergarten Entry Assessments in Pennsylvania}

In the Commonwealth of Pennsylvania, there is significant variation in kindergarten programs and the entry assessment systems, practices, and data used to support children entering school. There are no reliable data on the kindergarten entry assessment (KEA) systems used in public school districts across the Commonwealth. The types of instruments used, purposes for using KEAs, skill domains measured, and best practice strategies are mostly unknown in Pennsylvania schools. However, it is unclear if KEAs align with the Pennsylvania Early Learning Standards for Kindergarten and the professional development teachers receive for implementing KEAs. Moreover, there is no mandated entry assessment instrument for children who enter school in Pennsylvania (22 Pa. Code $\S 11.14$ ). The purpose of this study was to determine kindergarten teachers' knowledge and use of best practice strategies, purposes, whole child skill domains assessed, and professional development in regards to KEA in Pennsylvania schools to fill in some of the gaps in data. This study's results may provide information for future research on KEA in Pennsylvania and state and local professional development agencies. Over the past 12 years, there have been significant improvements in early childhood education programs. In 2007, Pennsylvania formed the Office of Child Development and Early Learning (OCDEL) to create a single department that serves the holistic, social-emotional, mental, behavioral, physical, and educational needs of young children from birth to Grade 3. Many early childhood teachers (P-3) have been credentialled through this unified office for early childhood education, including kindergarten teachers. An integrated and aligned data system to create a comprehensive KEA evaluation system that combines data sources across multiple state and 
local education and human service systems has also been developed, along with a robust training and technical assistance center for early childhood educators and programs.

To create consistency across kindergarten programs, support for teachers, and ease the transition to school for young children, the Pennsylvania OCDEL developed an assessment tool, the Kindergarten Entry Inventory (KEI), in 2017. The KEI is an optional tool that can be used by school districts that align with the Pennsylvania Early Learning Standards for Kindergarten. Alignment means the content, cognitive strategies, and complexity of the tasks are the same or similar between the KEI assessment items and the corresponding Pennsylvania Early Learning Standards for Kindergarten.

Kindergarten teachers use the Pennsylvania KEI (Pennsylvania Keys to Quality, 2017) to record students' demonstration of skills upon entry into school and obtain a snapshot of the child competencies. It also serves as an indicator of individual strengths and needs in these key learning areas: (a) social and emotional development; (b) language and literacy; and, (c) mathematics. KEI also assesses children's ability to learn through play, health, wellness, and physical development (A Guide to Using the Pennsylvania Kindergarten Entry Inventory, 2017). When teachers evaluate these skills together, they get a picture of the whole child. The information about a child's skills enables teachers to plan and implement instruction to increase student achievement in all skill areas assessed. KEI also provides a tool to communicate a child's progress with their family and provides state, district, and school leaders with data on kindergarten children's competencies.

In 2007, OCDEL created the Pennsylvania Keys to implement the work and support the policies developed and managed by OCDEL. The Pennsylvania Keys provides professional development and continuous quality improvement for all kindergarten teachers implementing the 
KEI. Teachers must obtain a completion certificate to access the web-based data system (A Guide to the KEI, 2017).

Pennsylvania kindergarten teachers' requirements were aligned with elementary education (K-6) teacher certification until 2013, when the classification was discontinued. Elementary education (K-6) and early childhood education (N-3) were both discontinued, and a new certification classification was developed to create more alignment within the continuum of early childhood education programs. The new classification for teacher certification is Grades PK-4 (preschool through fourth grade). This new certification creates a more integrated course of study that aligns preschool teacher competencies and elementary school-age teacher competencies in teacher preparation programs. New teachers graduating from higher education teacher preparation programs with grades PK-4 teaching certification will be better prepared to support children's seamless transition between preschool and kindergarten. The preschool through third grade (P-3) continuum illustrates the premise that if children are given a stronger start earlier in life between preschool and third grade, they will be more successful in Grades 412 and beyond (Kauerz, 2013).

Progress in improving the quality of early childhood education in Pennsylvania, including the KEA system, has been significantly increased since 2007. Still, the selection of instruments, skill domains measured, assessment practices, and purposes of the assessments used in kindergarten programs across Pennsylvania school districts are not fully known. Of the 500 school districts in Pennsylvania, only 70 use the KEI for kindergarten entry assessment. If children's needs are not accurately assessed, the instruction may not overcome environmental factors that contribute to ethnic, racial, linguistic, and socioeconomic disparities for many children entering kindergarten. Further, if there is a disconnect between kindergarten programs 
and preschool, transition challenges may be amplified for children already struggling. This transition challenge is especially true for children of color (Aikens et al., 2013; Mulligan et al., 2012; Larson et al., 2015; Reardon \& Portilla, 2016). Thus, there is a need to understand better how KEAs are used in Pennsylvania and how they address various children's diverse needs. The information gathered from this study can provide a better picture of schools' KEA status in Pennsylvania. The results may influence efforts by the Commonwealth of Pennsylvania to become a trauma-informed state (PCCD, 2020) and implement a model trauma-sensitive approach in schools (PDE, 2019). Local and state stakeholders could use the results to garner funding and resources for high-quality early childhood education programs, support integrated screening and assessment models that engage families. Also, collaborating with P-3 stakeholders to develop infrastructures, partnerships and build capacity to implement KEAs. Finally, to align administrative policies and legislation with advancements in brain science research to support healthy child development and positive outcomes for children, youth, and families (Jones et al., 2017). Finally, to inform state and local education, human services, higher education early childhood education teacher programs, and other child-serving professional development agencies to develop an integrated model of professional development and coaching to support the implementation of comprehensive KEAs in Pennsylvania schools. 


\section{Literature Review}

Children's transition from early childhood education programs to kindergarten has gained attention in the research over the past ten years (Commonwealth of Pennsylvania Governor's Office, 2015, 2016; Connors-Tadros, 2014; Schilder \& Carolan, 2014). Policymakers and other stakeholders have increasingly scrutinized the importance of early childhood education, the strength and needs of children entering kindergarten, assessment practices used, and funding necessary to support high-quality early education experience. There has been much debate over whether it is the role of schools alone to prepare young children for more formal learning in kindergarten or the broader community's role. The debate about who is responsible for ensuring young children's school readiness calls into question public investments in early childhood education. Schools, families, and early childhood care and education providers together can ensure children's foundational learning needs are met through quality early childhood learning opportunities along the birth through age eight continuum. The debate about who is responsible for ensuring young children's school readiness calls into question the investment in early childhood education. When we look at programs for children 4-5 years old, they become more connected to the local school district. These programs often function in silos with little communication between them to coordinate support for young children and their families, making the transition to kindergarten more difficult. This study looks at the components of KEA systems of teachers in Pennsylvania through a quantitative survey.

Early childhood is a critical period in the lives of children. During the early years of life, brain development is more rapid than at any other period (Sabol \& Hoyt, 2017). This development period sets the stage for future physical, cognitive, social, and emotional development that enables lifelong learning and success (Children's Defense Fund, 2014). 
Investing in the well-being of young children during this period is one of the most effective strategies for prevention, yielding lifelong benefits, including reducing the risk for future substance misuse and suicide (Djambazova-Popordanoska, 2016) and improving overall wellbeing (Hooper et al., 2010). As we consider this developmental period, easing the transition into school by intervening early to improve skill deficits or developmental delays is vital to set young children on a path to lifelong success. We must also consider this entry into school holistically rather than dependent only on the child being ready for school (Diamond, 2010; Espinosa \& Garcia, 2012; Friedman-Kraus et al., 2020; Yoder, 2014). We must look at every aspect of a child's development, including cognitive, physical, social-emotional, and relational domains at home and school, to provide the appropriate instruction and support to address the child's needs (Diamond, 2010; Roffey, 2016; Yoder, 2014).

This literature review examines research on KEAs in early childhood education over the last 20 years. First, I review research on comprehensive KEAs. I also review research on the understanding and reporting of kindergarten readiness by assessing child skills across cognitive and noncognitive skill domains, knowledge, and behaviors over time. I include research on the kindergarten entry/school readiness debate that considers racial, socioeconomic, and ethnic disparities and the significance of a high-quality entry assessment system to reduce the achievement gap and improve readiness. Next, I review research on best practice strategy recommendations by national organizations and research on the components or dimensions of currently used assessments that include the validity of the assessments, types of instruments, and assessment purposes used for KEAs. I explore the challenges for kindergarten teachers in using and interpreting assessments to identify areas for ECE/kindergarten teachers' professional development. I review instructional coaching's role to assist ECE/kindergarten teachers in 
using/interpreting assessments and providing professional development. Functions of the coaches and coaching effectiveness are outlined. Finally, I review research on current ECE/kindergarten assessment practices in Pennsylvania to develop a case study evaluation to determine if Pennsylvania has unique problems in KEA systems.

The rationale for studying Pennsylvania Commonwealth public schools is to determine the use of kindergarten assessments and the barriers to implementing the KEA in Pennsylvania schools. Pennsylvania has a standard definition of kindergarten readiness, and it takes into account; (a) a child's comprehensive set of skills (cognitive and non-cognitive) and (b) the teacher's and school's ability to meet the needs of all children. The definition of readiness includes (a) a teacher's focus on reflective practice (learning environment, pedagogy, school structures); (b) the family's readiness to share information and advocate for their child; and (c) the community's readiness to provide services to ensure positive learning environments (OCDEL, 2017). What is not known is how or whether kindergarten programs implement the definition's components. There is no research specific to Pennsylvania that has obtained data on KEA practices.

\section{Comprehensive Early Childhood Education/Kindergarten Assessment System}

In the broadest sense, school readiness is about children, families, early environments, schools, and communities. Children are not innately ready for school, and it is up to the entire community to create a culture of learning. One way to assess kindergarten readiness is through a thorough assessment. The process of conducting KEAs provides an opportunity to intervene early and ensure early childhood education practices are the most effective in providing a strong foundation for learning. When we address skill deficits early, we can positively impact a child's 
lifelong learning experience and success for individual children, impacting the collective community (Maxwell \& Clifford, 2004).

A significant body of research shows the value of the investment in early childhood education because of long-term improvement in cardiovascular health (Sabol \& Hoyt, 2017), emotional regulation, which impacts attention and following teacher directions (DjambazovaPopordanoska, 2016), social-behavioral outcomes (Hooper et al., 2010), and reading and math achievement in later grades (Aikens et al., 2013; Bassok et al., 2016; Baumgartner, 2017;

Bettencourt et al., 2016; Bradbury et al., 2015; Bridgeland et al., 2013; Buysse \& Hollingsworth, 2009; Copple \& Bredekamp, 2009; Curby et al., 2015; Denham et al., 2014; Domínguez et al., 2010; Dusenbury et al., 2015; Education Commission of the States, 2014; Grafwallner et al., 2015; Hatcher et al., 2012; Marope \& Kaga, 2015; National Research Council, 2008; Pagani \& Fitzpatrick, 2014; Pritzker et al., 2015; Sabol \& Hoyt, 2017).

Thus, it is clear early childhood education is critical for lifelong development and learning. However, while there have been substantial increases in federal and state funding (Early Learning Challenge Technical Assistance, 2015; U.S. Department of Health and Human Services, 2010) to support early childhood education improvements (Baker et al., 2013; Baumgartner, 2017; Bettencourt et al., 2016; Bradbury et al., 2015; Copple \& Bredekamp, 2009; Early Learning Challenge Technical Assistance, 2015; Grafwallner et al., 2015; Justice et al., 2015; Kornrich \& Furstenberg, 2013; National Association for the Education of Young Children [NAEYC], 2009; National Research Council, 2008; Repko-Erwin, 2017), there are no state-mandated assessments for children who enter school in Pennsylvania (22 Pa. Code $\S$ 11.14). 
Kindergarten assessments exist within a more extensive preschool through third grade (P3) early childhood system that supports developmentally and culturally appropriate learning across the grade levels (Friedman-Krauss et al., 2020; Keily et al., 2019; Roffey, 2016; Saracho, 2015; Snow, 2011). "P-3" is the term used to define approaches intentionally designed to align children's learning experiences before formal school entry (preschool) with those in the primary grades of elementary school $(\mathrm{K}-3)$. The vision for P-3 approaches is to improve the quality and coherence of children's learning opportunities, from the experiences children have before they enter the K-12 system and extending through elementary school (OCDEL, 2017). Ultimately, comprehensive P-3 approaches have the potential to improve child outcomes and prevent or close achievement gaps.

KEA systems can help ensure children develop the cognitive and social skills needed for future learning (Little \& Cohen-Vogel, 2016; Scherer, 2009). Specific characteristics should be included in early childhood assessments. For instance, kindergarten assessment should be a continuous and ongoing process aligned to state early learning standards, instructional practices, and curricula (Marope \& Kaga, 2015; Race to the Top-Early Learning Challenge, 2009; Smylie, 2014; Stewart, 2014). Also, ethical principles should guide assessment practices. They should benefit the children with whom the assessments are used (NAEYC \& NAECS/SDE, 2003; Niemeyer \& Scott-Little, 2001; Regenstein et al., 2017; Scherer, 2009; Son \& Peterson, 2017). Moreover, an efficient KEA system should not waste time or money, be comprehensive, and include multiple assessment components to address barriers and gaps in children's skills. Assessments include screening, diagnostic, formative, and summative forms. Furthermore, kindergarten assessments should be valid and reliable tools that assess whole-child skills (academic skills, language, nonacademic social-emotional skills, and school-related skills; Daily 
\& Maxwell, 2018; Darling-Hammond, 2010; Darling-Hammond \& Cook-Harvey, 2018). The integration of the assessment into daily learning contexts for instructional decision making, cultural and linguistic responsivity, monitoring changes in learning behavior over time, and PreK through Grade 3 continuum standards (Espinosa \& Garcia, 2012; Ghandour et al., 2019) are additional recommendations.

To ensure appropriate integration into daily learning contexts, a responsive coaching model supports teachers' professional growth (Jones et al., 2016; Kraft et al., 2018; Kurz et al., 2017; Snow, 2011). Finally, the assessments need a defined purpose, guided by ethical and developmentally appropriate practices, and provide for teacher growth through professional development and coaching (Gallagher \& Bennett, 2018). In the next section, I review the uses of KEAs to determine child skills across cognitive and noncognitive skill domains, knowledge, and behaviors over time using best practice strategies and a whole-child approach.

\section{Assessments of Children's Skills, Knowledge, and Behaviors}

The whole-child approach to assessment and teaching supports and nurtures all areas of children's development and learning - from social-emotional and cognitive skills to literacy, math, and science understanding — and is a powerful strategy as preschool children transition to kindergarten. Using a whole-child approach encourages children's learning and thinking by teachers being responsive to children's understandings, interests, and abilities, allowing them to deepen their natural curiosity and their eagerness to want to discover and learn more (NAEYC, 2009; Schachter et al., 2019, Schachter et al., 2020). Children enter kindergarten with varying levels of skills across a variety of domains. Social, cognitive, and emotional skills are typically assessed by KEAs (Abry et al., 2017; Hatcher et al., 2012; Obradović et al., 2006; Ray \& Smith, 2010). When children attend preschool, the social, cognitive, and emotional skills they learn are 
a strong foundation for their transition to a kindergarten program (Curby et al., 2015; Denham et al., 2014; Desimone, 2011; Dusenbury et al., 2015). Children who do not have preschool experiences may lack essential skills that prevent them from being successful. When children lack specific skills or fail to develop these skills, they may be eligible to receive supplemental and specialized instruction and academic or behavioral support through an individualized education plan or 504 plan.

A comprehensive assessment system is necessary to measure children's knowledge and skills, as identified in Pennsylvania state education standards (PDE, 2017). Such a system can provide teachers and administrators with the tools necessary to achieve the appropriate developmental age and whole-child outcomes. The results can determine students' mastery and assist instructional decision making in early childhood education (OCDEL, 2016) by providing an accurate and holistic picture of the children's strengths and needs.

The OCDEL (2017) outlined the critical learning areas necessary for inclusion in KEAs that align with Pennsylvania Early Learning Standards for Kindergarten. The key areas are: (a) learning through play assesses children's skills in constructing, organizing, and applying knowledge; (b) language and literacy measure English language arts skills; (c) mathematical thinking and expression measures exploring, processing, and problem-solving skills; (d) scientific thinking measures exploring, inquiry, and discovery skills; (e) social studies thinking measures a children's connections to their communities; (f) creative thinking and expression measures communication through the arts; (g) health, wellness, and physical development measures understanding of a child's own body; (h) social and emotional development measures child interpersonal skills; and, (i) partnerships for learning assesses the children's families, learning environments, and communities. These skills form the foundation for assessment, 
curriculum, instruction, and intervention in early learning settings such as kindergarten. Critical skills for KEA and instruction identified in the research are shown in Table 1. 


\section{Table 1}

Critical Skills for KEA and Instruction

\begin{tabular}{|c|c|}
\hline Author (Publication Date) & "Whole child" early learning/kindergarten readiness/entry skills \\
\hline Walsh (2005) & $\begin{array}{l}\text { Physical well-being and motor development } \\
\text { Social and emotional development } \\
\text { Approaches to learning } \\
\text { Language development } \\
\text { Cognition and general knowledge }\end{array}$ \\
\hline $\begin{array}{l}\text { McDermott, Rikoon, } \\
\text { Waterman, \& Fantuzzo } \\
\text { (2012) }\end{array}$ & $\begin{array}{l}\text { Positive learning behaviors are: } \\
\text { Ability to work well with others } \\
\text { Attempt novel tasks } \\
\text { Show appropriate determination or effort to complete a given task } \\
\text { Accept needed help without becoming aggressive or hostile }\end{array}$ \\
\hline $\begin{array}{l}\text { Race to the Top-Early } \\
\text { Learning Challenge (2009) }\end{array}$ & $\begin{array}{l}\text { Social skills } \\
\text { Emotional skills } \\
\text { Cognitive skills }\end{array}$ \\
\hline $\begin{array}{l}\text { U.S. Department of Health } \\
\text { and Human Services (2010) }\end{array}$ & $\begin{array}{l}\text { Head Start child development and early learning framework-11 domains: } \\
\text { Physical development and health } \\
\text { Social and emotional development } \\
\text { Approaches to learning } \\
\text { Language development } \\
\text { Literacy knowledge and skills } \\
\text { Mathematics knowledge and skills } \\
\text { Science knowledge and skills } \\
\text { Creative arts expression } \\
\text { Logic and reasoning } \\
\text { Social studies knowledge and skills } \\
\text { English language development (only to ELL) }\end{array}$ \\
\hline $\begin{array}{l}\text { National Research Council } \\
(2008)\end{array}$ & $\begin{array}{l}\text { Physical well-being and motor development } \\
\text { Social and emotional development } \\
\text { Approaches toward learning } \\
\text { Language development (including emergent literacy) } \\
\text { Cognition and general knowledge (including mathematics and science) }\end{array}$ \\
\hline $\begin{array}{l}\text { Pennsylvania Office of Child } \\
\text { Development and Early } \\
\text { Learning (2017) }\end{array}$ & $\begin{array}{l}\text { Approaches to learning through play } \\
\text { Language and literacy } \\
\text { Mathematical thinking and expression } \\
\text { Scientific thinking } \\
\text { Social studies thinking } \\
\text { Creative thinking and expression } \\
\text { Health, wellness, and physical development } \\
\text { Social and emotional development } \\
\text { Partnerships for learning }\end{array}$ \\
\hline
\end{tabular}


In the next section, I describe the kindergarten entry/school readiness debate that examines stakeholders' responsibility to ensure children enter school ready to learn.

\section{The Kindergarten Entry/School Readiness Debate}

The kindergarten entry/readiness debate is about whether students should enter school with the skills to learn and be successful. Schools, families, and the community are responsible for meeting children's needs through instruction that addresses a mix of cognitive and noncognitive skills across environments. This debate has the most significant implications for children from low socioeconomic, predominantly Black and Hispanic households. Educators, policymakers, and school administrators recognize children growing up in high poverty communities (Chetty et al., 2016; Reardon \& Portilla, 2016) often enter school at a significant disadvantage relative to children living in higher socioeconomic communities. Socioeconomic, racial, and ethnic disparities account for most of the achievement gap in primary and secondary school achievement (Bradbury et al., 2015; Grissmer \& Eiseman, 2008; Duncan et al., 2014; Magnuson et al., 2004). Low-quality early childhood care and education can damage children's growth and development across all racial and ethnic groups. The damage is more significant if early childhood education programs fail to address the disparities and disadvantages children face in the early developmental phase of their lives (Manning et al., 2015).

In Pennsylvania, access to kindergarten depends on the school district and individual school initiatives and resources. Thus, kindergarten provision is an educational equity issue as not all children attend kindergarten. There is no requirement in Pennsylvania to attend kindergarten (PDE, 2012). Before 2019, Pennsylvania state laws on compulsory education lagged behind most states by not requiring children to enroll in school until age 8 . Effective the 2020-2021 school year, a child living in Pennsylvania must comply with compulsory attendance 
requirements from ages 6 to 18 (PDE, 2020). This new requirement aligns with most states throughout the country. However, the lack of required kindergarten for school districts makes KEA, the professional development tied to KEA, and resources to implement a comprehensive entry assessment system less appealing to the policymakers in charge of decision making for their school district. Next, I look at the significance of conducting a comprehensive KEA system and its implications for child outcomes.

\section{The Significance of Assessment}

Teachers and administrators' use of high quality and comprehensive early childhood and KEA systems may reduce the kindergarten readiness and achievement gap. For instance, ecological instability can be a contributor to children's lack of kindergarten readiness. Such instability is characterized by family residence changes, parent marital status, co-residence with extended family members, childcare type and hours, and maternal employment status (Fomby \& Mollborn, 2017). Also, limited resources for families in poverty impacts the amount of time for reading to their children and the availability of other educational materials (Duncan \& Murnane, 2011; Kornrich \& Furstenberg, 2013; Duncan et al., 2014; Magnuson \& Waldfogel, 2015) and enrichment activities (Kaushal et al., 2011; Walker et al., 2011). Children's knowledge and skills can vary widely by as early as five years of age, regardless of background (Aikens et al., 2013; Larson et al., 2015; Mulligan et al., 2012; Reardon \& Portilla, 2016).

Exposure to trauma or chronic stress harms several domains of functioning related to school performance. Higher traumatic stress symptoms predict lower reading, math, and science achievement scores among elementary students (Goodman et al., 2012). Children experiencing stress and disturbances struggle to learn new information when affected by trauma, limiting their capacity to receive and integrate new information such as social-emotional skills (Van der Kolk, 
2014). Traumatic exposure at home, school, or in the community has been associated with PTSD and higher rates of separation anxiety, social anxiety, depression, suicidal ideation, and oppositional and aggressive behavior (Overstreet \& Mathews, 2011). Additionally, traumatic symptoms are associated with a three-fold increase in odds of having an Individualized Education Program for learning or behavior problems (Goodman et al., 2012). Adverse childhood experiences include neglect, abuse, and poverty, which have harmful, often lifelong effects on children's health, relationships, and academic achievement (Burt et al., 2012; Faletti et al., 1998; Finkelhor, 2009; Finkelhor et al., 2011; Greeson et al., 2013; Prevention Institute, 2014). Traumatic events such as community violence interfere with young children's attainment of critical competencies - cognitive, sensory, muscular, emotional, social, and behavioral — and compromises caregivers' capabilities to provide supportive environments for children (Cronholm et al., 2015; Maggi et al., 2010). Many contextual factors can have significant impacts on children's outcomes. A comprehensive KEA can play a pivotal role in reducing negative impacts on children by creating a collaborative system of evaluation and support that identifies the child and their family's needs and provides timely, integrated services to address needs. Next, I review how kindergarten programs can improve readiness for all children.

\section{Improving Kindergarten Readiness}

Comprehensive early childhood education systems can ameliorate some of these adverse experiences by providing a safe and caring environment that builds positive relationships between teachers and children and providing access to human service supports for the entire family (Anda et al., 2006; Anda et al., 2010; Bethell et al., 2014; Shonkoff et al., 2012). As classrooms become more diverse, so do the needs of the children. There is no one definition of diverse learners. The description of diverse learners has evolved to include individuals whose 
race is other than the United States' dominant European group (SEDL, 2012). In addition to children of color, including Muslim, Latinx, English Language Learners (ELL), Indigenous people, and children of low socioeconomic status (Hulse, 2020; Khalifa, 2018), the LGBTQ population, or children with disabilities. The Southwest Educational Development Laboratory (SEDL, 2012) describes diverse learners as those living in rural areas, homeless, migrant, neglected, or delinquent, American Indian, Native Hawaiian, or Alaska Natives; or attend schools in districts that receive impact aid for diverse learners (SEDL 2012). The definition of diverse learners may change with the population. All learners are unique. It is important to note that diverse learners will have overlapping features within and across each category of diversity and within the local context.

Culturally competent assessments account for the child and family's cultural, social, and linguistic backgrounds in the assessment process. Culturally competent assessments support whole-child education and instructional decision making and identify support for the family as a foundation for children's lifelong learning and success. Children are more likely to experience a level playing field in kindergarten when cultural, individual, and developmental perspectives are considered in the assessment process. A comprehensive early childhood education system, including assessment and instructional decision-making, aligned to state early learning standards, addresses disparities in diverse learners' needs. A KEA system responsive to the individual child and family's needs creates more equitable learning opportunities. Next, I review kindergarten assessment best practices recommended by national organizations and previous research to ensure equitable practices. 


\section{Best Practice Strategies of Kindergarten Entry Assessments}

Because of the critical nature and complexity of assessment in early childhood education, several national organizations convened to develop and disseminate sound practices in evaluating young children (NAEYC \& NAECS/SDE, 2003). These organizations urge the widespread use of developmentally appropriate, culturally and linguistically-responsive measures tied to children's daily activities (Howard, 2011). Culturally, linguistically responsive assessments identify family and child-specific strengths and needs and include the perspectives of parents, educators, and cultural brokers who provide insights into vital cultural practices and expectations (Kirova \& Hennig, 2013). The KEA should also build on students' individual cultural experiences by administering assessments in children's native language (Brown et al., 2007). Connections to the child's experiences activate their prior knowledge and connect the assessment to their cultural and linguistic context

Moreover, national organizations urge an assessment system that provides evidence of children's learning over time and reflects children's varied, real-world contexts (NAEYC, 2009). These best practices provide an array of educational opportunities that foster growth for children's academic and nonacademic skills (Ray \& Smith, 2010). When children receive assessment and instruction more consistently, comprehensively, and with the greatest chance of success possible, they are more likely to continue growing.

Kindergarten assessments should be part of a comprehensive instructional decisionmaking process by teachers aligned to early childhood education standards. Multiple assessment formats provide the most comprehensive picture of children's competencies, yielding information on learning by measuring students' growth over time (Domínguez et al., 2010). The teacher can use the data to make instructional decisions on what to teach and how to schedule their 
instructional time (Gullo \& Hughes, 2011; Halle et al., 2011; Pyle \& DeLuca, 2013). Ethical principles should guide assessment practices, and these should benefit the children with whom the assessments are used (NAEYC \& NAECS/SDE, 2003; Niemeyer \& Scott-Little, 2001).

Comprehensive early childhood education systems that are collaborative across grade levels help teachers provide more consistent instruction and learning environments that benefit all children throughout their schooling. This consistency from birth through Grade 3 and beyond allows children to develop foundational academic and nonacademic skills from one year to the next (Wat, 2012). Not only can KEAs identify children with more intensive needs for instructional decision making, but they can also identify children with more advanced skills to focus on moving them forward. Next, I review the components that comprise current assessments.

\section{Assessments Components}

Assessment is the process of gathering information about a child from several forms of evidence, then organizing and interpreting the information for varying purposes (OCDEL, 2017). Assessments need a defined purpose, guided by ethical and developmentally appropriate practices. The type of assessment instrument selected and the purpose of assessment are interdependent (Niemeyer et al., 2002). Administrators and teachers select an assessment instrument based on the skills they want to assess and what they want to do with the data. An efficient KEA system should not waste time or money, needs to be comprehensive, and must both formative and summative measures. Formative and summative measures use a variety of formats (portfolios or structured observations) for cognitive and non-cognitive skill domains across school, home, and community contexts. They can identify gaps in kindergarten children's skills. Assessments of whole child skills (academics skills, including language, social-emotional 
skills, and school-related skills) should occur in the first 45 days of school. Assessments should be integrated into daily learning for instructional decision-making and consider students' unique cultural and linguistic needs. Assessments can be used to monitor changes in student learning behavior over the year. The KEA system includes a seamless progression of academic and nonacademic standards for Pre-K through third-grade children (Jacobson, 2016). In the next section, I will review the types of KEAs available to Pennsylvania teachers.

\section{Types of KEA Instruments}

Assessments should align with the curriculum and the instruction in classrooms.

Gathering information on children's skills at kindergarten entry can set the stage for instruction and curricula to significantly impact students' learning. The selection and use of assessment instruments that capture the most accurate information is critical to student success (OCDEL, 2017).

OCDEL outlined a framework for a comprehensive and aligned assessment system for Pennsylvania educators to use with children from birth to age 8. Four types of assessments are: screenings; diagnostic assessments; formative assessments; and summative assessments (Pagani \& Fitzpatrick, 2014; Weisenfeld, 2017a; Weisenfeld, 2017b). Screeners are brief, easily administered by teachers, and used with large groups of children to determine if they currently meet developmental milestones. Those who do not may receive further evaluation. Diagnostic assessments identify learning, sensory, neurological, language, and behavioral disabilities that require special education services (Regenstein et al., 2014). Formative assessments assess progress in the academic and non-academic skills of children. These may be informal or formal tools that inform instructional decision-making (Nuttall et al., 2017). Summative assessments are often standardized tests that measure a child's skills following instruction and at specific 
intervals, such as the end of an instructional unit. Summative assessments may inform policy, resource distribution, and practice, and engage stakeholders and policymakers (Grafwallner et al., 2015).

Several states use standardized assessments for KEA. Among these assessments are the BRIGANCE Early Childhood Kindergarten Screen III, the Desired Results Developmental Profile (DRDP), the Phonological Awareness Literacy Screening for Kindergarten (PALS-K), Qualls Early Learning Inventory (QELI), STAR Early Literacy, and Teaching Strategies GOLD (Education Commission of the States, 2014). Pennsylvania does not, however, require a standardized assessment for KEA. Local school district administrators and school boards often decide on the assessment instruments used for KEA. Teachers may have input or complete control over the selection of the assessments they use (22 Pa. Code $\S 11.14$.). Next, I review the purposes of KEAs.

\section{Purposes of KEA}

Information gathered from assessments informed the learning environments' design to help children grow to their optimal developmental potential. The Federal Race to the Top-Early Learning Challenge (RTT-ELC, 2015) competition aimed to improve early learning and development and close the achievement gap for children with high needs. Challenge grants were significant drivers in the recent development and revision of KEAs across the country. Pennsylvania was awarded an RTT-ELC grant leading to the development of the KEI. The RTTELC provided the most detail regarding the definition of KEAs and recommended that states develop an assessment system administered to children during the first few months of their admission into kindergarten. The RTT-ELC also called for assessments to be valid and reliable, and aligned to the state's Early Learning and Development Standards. Assessments should not be 
used to prevent children's entry into kindergarten (U.S. Department of Education, 2011), but instead, should help determine how to meet children's needs best.

Through the RTT-ELC funding in 2015, Pennsylvania made improvements in delivering high-quality instruction, increasing access, and delivering high-quality professional development. These efforts were to revise early learning standards in all content areas to fully align with Pennsylvania's education standards (PA, Race to the Top, 2015). This new alignment situates kindergarten programs as strongly connecting early childhood education and school-age grade levels, ensuring a cohesive set of standards from birth through 12 th grade. The Pennsylvania Early Learning Standards for Kindergarten are the foundation of the Pennsylvania KEI.

Some programs have used KEA to determine the "readiness" of children. As a result, some children may be deemed "not ready" for school (Joseph \& Strain, 2003; Webster-Stratton et al., 2008; Zins et al., 2004). Gray (1985) identified two distinct perspectives on delaying a child's entry to kindergarten. The first is to delay the child's entry into kindergarten until the child can reasonably perform the tasks typical of a kindergarten child. The second perspective is to enroll the child when the child reaches a certain age and then provide the educational program that can be expected to meet the child's needs successfully. Both perspectives acknowledge that a child's developmental age may differ from the chronological age (Gray, 1985). Delaying kindergarten has been associated with negative consequences for learning (Bassok \& Reardon, 2013), and may have harmful long-term consequences (Chetty et al., 2016; Reardon \& Portilla, 2016). Delayed entry presents lost opportunities for many children, thus, potentially widening the achievement gap. However, some research shows a delayed entry of one year may improve children's non-cognitive skills (Muhlenweg et al., 2019), self-confidence, and positive risk- 
taking (Page, Sakar \& Silva-Goncalves, 2019). Results also showed a reduced probability of grade retention (Barua \& Lang, 2008), less likely to be diagnosed with a learning disability, and more likely to attend a college or university (Hover, 2018), and are less likely to develop behavioral problems and speech impediments. Children with learning disabilities, ADHD, and dyslexia/dyscalculia remain unaffected by delaying entry (Balestra, Eugster \& Liebert, 2019). Greenburg \& Winsler (2020) found that most students in a predominantly low-income sample had lower school readiness skills before delayed entry. Boys with lower readiness skills were both white and children of color. However, programs have been directed not to use KEAs to delay school entry. Pennsylvania's local decision-making system of school boards and administrators does not mandate this practice's exclusion (22 Pa. Code $\S 11.14$.).

\section{Challenges to Implementing the KEA System}

Thus far, the literature reviewed has underscored KEA's significance; however, KEA is not mandated in Pennsylvania (Ackerman, 2018a; Ackerman \& Lamber, 2020). There are at least six challenges to implementing KEAs. It is useful to understand these challenges to overcome them (Ackerman, 2018b; Carver-Thomas \& Darling-Hammond, 2017; Curran et al., 2020; Espinosa \& Garcia, 2012). One challenge is the amount of time teachers need to conduct assessments collaboratively, comprehensively, and objectively analyze the data. Second, teachers may be biased toward seeing their students perform well (Saracho, 2015). Although others could conduct the assessments, young children may not perform well for people they do not know well (Ghandour et al., 2019; Goldstein \& Flake, 2016). Also, if teachers are not involved in the assessment, it may be more challenging to modify students' instruction. Third, children's relationships with adults in school regularly change, limiting the validity of the assessments. Taking multiple measures over time helps to alleviate this challenge. Fourth, teachers often have 
limited skills to administer assessments to diverse groups of children, analyze the data, and modify instruction based on the outcomes. There are often limited resources to train teachers on how to use assessments appropriately. Fifth, kindergarten teachers have limited time to conduct assessments, plan and collaborate with peers, and attend to additional responsibilities such as professional development or coaching. Sixth, kindergarten teachers may not receive the institutional support they need (Leiber et al., 2009). Next, I review the need for ECE/kindergarten teacher professional development and its connection to KEA.

\section{Need for ECE/Kindergarten Teacher Professional Development}

In particular, beginning teachers decide to leave teaching due to lack of adequate support from their administrators, inability to manage personal and professional expectations, limited teaching resources, lack of professional development, and difficulty handling behavioral problems in the classroom (Ingersoll, 2014). These challenges are more pronounced among early childhood educators from Pre-K through third grade and lead to higher staff turnover rates (Cappelloni, 2011; Early et al., 2007).

One way to mitigate teacher attrition is through professional development (CarverThomas \& Darling-Hammond, 2017; Wang, 2017). Students need high-quality instruction and consistent support. Assessment delivered with fidelity is critical to providing high-quality instruction delivered with implementation fidelity. Critical features of quality professional development include: (a) content focus on the subject matter; (b) teachers having opportunities to gen involved in their learning; (c) professional development consistent with teacher knowledge, beliefs, and school, district, and state regulations; (d) 20 hours or more spread over a semester or longer; and, (e) collective participation from teacher groups (Desimone, 2011). Fidelity of implementation requires teacher professional development with evidence-based instructional 
coaching for effective implementation and lasting change (Justice et al., 2015; Landry et al., 2009; Landry et al., 2006), and greater student achievement (Martin et al., 2010).

Policies governing teacher evaluation systems tend to make only weak provisions for professional development and fail to ensure that such opportunities are high quality and valuable to improving practice (Smylie, 2014). There is a need for high-quality professional development, including coaching and active learning to support early childhood teachers as just a few key components (Joyce \& Showers, 2002; Wanless et al., 2013; Wanless et al., 2015). Next, I review instructional coaching to assist kindergarten teachers in interpreting and using assessments.

\section{Instructional Coaching to Assist Kindergarten Teachers in Using/Interpreting Assessments}

Teacher professional development and coaching is necessary to prepare kindergarten teachers to use and interpret KEAs. Kindergarten teachers should (a) have a good understanding of the diverse subject matter for the instruction of academic and nonacademic skills; (b) the kindergarten curriculum and how to adapt it according to children's abilities; (c) the learners' needs; (d) understand the processes, methods, and techniques of assessment and instruction; (e) be familiar with the school, and the local education system context; and, (f) understand their strengths and weaknesses in these competencies as a teacher professional (Pianta et al., 2014). Accomplishing these teacher competencies requires ongoing professional development and coaching to establish and sustain the skills long after the KEA's initial training (DarlingHammond, 2014; Joyce \& Showers, 2002; Kunter et al., 2013; Lino, 2014; Schachter, 2015; Stewart, 2014). Instructional coaching is a model for delivering professional development to improve teacher competencies. Teacher professional development and coaching are necessary to train and assist kindergarten teachers in using and interpreting KEAs (OCDEL, 2017). Coaching 
provides long-term support and guidance and should feature collaborative systems change for the entire birth through age eight workforce (Conners-Tadros et al., 2015; Smylie, 2014).

\section{Functions of ECE/Kindergarten Coaches}

KEA data collection requires that kindergarten teachers and other staff conducting the assessments have good self-reflection, student, and learning context observation skills. These skills have been the target of a specific type of professional development, instructional coaching (Capella et al., 2016; Casey \& McWilliam, 2011; Collet, 2015; Connor, 2017).

Instructional coaching emphasizes teachers' development. Critical elements of coaching are; (a) knowledge of teacher (or team) and their desired learning; (b) providing feedback to improve school performance; (c) allowing educators opportunities to apply new skills; (d) supporting teachers to self-reflect, (d) facilitating peer-to-peer observation with feedback; and, (e) and facilitating self-directed teacher goals for improvement (Moody, 2019; Elek \& Page, 2019). Nonevaluative feedback from a school leader complements coaching. Coaches also need processes to develop instruction, experiment with new approaches, solve problems, and build collegial relationships (Copple \& Bredekamp, 2009; Hochberg \& Desimone, 2010; Martin et al., 2010; Martinez, 2016; Rush et al., 2003; Schachter, 2015). They may provide individual coaching sessions with a teacher, facilitate professional learning communities (PLCs), and coach conversations to address instructional practices. The coach's role is to provide a support system for kindergarten teachers to develop the skills to assess kindergarten children's academic and nonacademic skills. They also collect and analyze data, design and adjust instruction based on the students' needs, and provide evidence-based programming with fidelity to ensure the validity of instruction (Collet, 2012, 2015; Connor, 2017; Darling-Hammond, 2010). The coach functions as a support rather than a supervisor; thus, coaches have a trusting professional relationship with 
the teacher, competency in coaching skills, and a goal to improve the skills of the kindergarten teacher they are coaching (Denton \& Hasbrouck, 2009; Desimone \& Pak, 2017; Ingersoll et al., 2018). Every aspect of teachers' KEA system implementation is taught, reinforced, and sustained through coaching. Next, I review evidence of coaching effectiveness to ensure positive teacher and student outcomes related to KEA.

\section{Evidence of Coaching Effectiveness}

The growing literature on teacher coaching provides a needed evidentiary base for teacher development policy, practice, and research (Kraft et al., 2018). Cornett and Knight's (2009) review of research showed that coaching improves: (a) teachers' attitudes; (b) skills; (c) feelings of efficacy; and (d) student achievement. Teemant et al. (2011) found instructional coaching led to statistically significant: (a) teacher pedagogical improvement; (b) improvement in urban teacher practices; and (c) sustainability one year after the end of coaching. Collet (2012) found that when coaches model, make recommendations, ask probing questions, affirm teachers' appropriate decisions, and offer praise, teachers become more independent and collaborative. Pooling results from across 60 studies of teacher coaching programs. Kraft et al. (2018) found large positive effects $(p=0.49 ; p<.001)$ on instruction and smaller positive effects $(p=0.18$; $p<.001)$ on achievement.

Coaching to improve teacher practices provides a significant professional development method that supports teachers in implementing KEA. The challenges present when implementing a comprehensive KEA system can be mitigated through effective and efficient coaching. The research clearly shows coaching is useful for long-term improvement in teacher practice. Next, I review KEA practices in Pennsylvania. 


\section{KEA Practices in Pennsylvania}

Recent efforts in the Commonwealth of Pennsylvania over the past 12 years have resulted in significant improvements to early childhood education programs. Increases in the number of high-quality early childhood education programs afford more generous access to families. In 2007, Pennsylvania formed the Office of Child Development and Early Learning (OCDEL) to create a single department that serves the needs of young children from birth to Grade 3 and their families. This unified state office integrates human service and educational systems in Pennsylvania and supports all early childhood providers serving young children and their families across the Commonwealth. A framework of supports and policies ensure all children and their families have access to high-quality services. OCDEL has an integrated and aligned system that combines data sources across multiple state and local education and human service systems to create a seamless service delivery system for educators.

Pennsylvania has supported comprehensive PreK to third-grade early childhood assessment systems. However, the selection and purposes of the assessments used in approximately 8065 Pennsylvania kindergarten programs are unknown. Also, the professional development that teachers receive to support KEAs is not fully known. The uses and types of KEAs vary among Pennsylvania schools, and there are no reliable data on the kindergarten readiness assessments used in public school districts. The Commonwealth of Pennsylvania government structure gives absolute decision-making power to school districts. Thus, little information is reported to the state. This structure impedes the creation of a unified KEA process that meets school districts' needs.

There is evidence to support the significance of KEA to student transitions and outcomes (Commonwealth of Pennsylvania Governor's Office, 2015, 2016; Connors-Tadros, 2014; 
Djambazova-Popordanoska, 2016; Hooper et al., 2010; Kauerz, 2013; Sabol \& Hoyt, 2017;

Schilder \& Carolan, 2014). KEA is associated with improvements in children's academic performance in grades 4-12 and risk reductions for future substance misuse and suicide (Djambazova-Popordanoska, 2016; Children's Defense Fund, 2014).

The primary purpose of the Pennsylvania KEI is to provide scientifically valid information about young children's physical, personal, social, emotional, and cognitive skills upon entry into school. The KEI provides kindergarten teachers with a snapshot of children's competencies at kindergarten entry. Presumably, such information will help teachers tailor their instruction to meet individual student needs. A secondary purpose is to provide state, district, and school leaders with data on kindergarten children's competencies. Seventy out of 500 school districts (14\%) in Pennsylvania use the KEI.

This study's focus was to identify current KEA practices in Pennsylvania. This information may inform professional development practices for implementing KEA.

\section{Research Focus and Research Questions}

The following research questions are of interest in this study.

1. What kindergarten entry assessment practices are used by PA kindergarten teachers?

2. What kinds of professional development and coaching do kindergarten teachers receive to perform kindergarten entry assessments?

3. Are there differences in teachers' and administrators' knowledge and views of kindergarten entry assessment practices? 


\section{Method}

\section{Participants}

Kindergarten teachers and administrators were recruited from 2179 public elementary schools in 483 Pennsylvania school districts and 126 Pennsylvania public charter schools. All schools had a 5-year-old kindergarten classroom. Children in all 67 Pennsylvania counties have access to at least one public, inclusive (K-5) kindergarten program between the school districts and charter schools in the Commonwealth of Pennsylvania. Participants were identified through purposeful sampling. Inclusion criteria included the respondent holding a supervising or teaching position in an inclusive (regular education and special education) kindergarten classroom with children who were no less than five years of age. Excluded from the sample were teachers teaching in kindergarten programs for children under four years old (K4) and private schools, due to the smaller sample size. Teachers in specialty programs for early intervention services or programs for children with special needs in a segregated program were also excluded.

\section{Sample Characteristics}

Respondents included 48 teachers (93.75\% White, 4.17\% Hispanic, 2.08\% Black/African American, and 100\% female) and 22 administrators (95.45\% White, 0\% Hispanic, $4.76 \%$ Black/African American, 61.90\% female, and 38.10\% male) completed a survey used to assess kindergarten entry assessment (KEA) practices and professional development. The total number of kindergarten teachers in Pennsylvania is unknown.

Table 2 shows the experience categories based on the number of years teaching (teachers) or supervising (administrators). The frequency is highest for teachers with ten years or less of teaching experience $(n=24)$, with 11-20 years of experience $(n=13)$ being the next largest group. Administrators with ten years or less supervising experience $(n=11)$ were the largest 
group, followed by administrators with 11-20 years of supervising experience $(n=10)$. Overall, the largest group of teachers and administrators had less than ten years of experience teaching or supervising. The second largest group were teachers and administrators with 11-20 years of experience teaching or supervising.

\section{Table 2}

Years Teaching (Teachers) or Supervising (Admin) by Role

\begin{tabular}{llrrrr}
\hline \multicolumn{5}{c}{ Years of Teaching/Supervising } \\
\hline Group & Teacher & $24(50.0 \%)$ & $13(27.1 \%)$ & $11(22.9 \%)$ & 48 \\
& Administrator & $11(50.0 \%)$ & $10(45.5 \%$ & $1(4.5 \%)$ & 22 \\
\hline Total & & $35(50.0 \%)$ & $23(32.9 \%)$ & $12(17.1 \%)$ & 70 \\
\hline
\end{tabular}

\section{Measure}

Two versions of an online Qualtrics survey were used to gather data. Kindergarten teachers completed the Kindergarten Entry Assessment-Teacher survey (see Appendix A). Elementary school administrators completed the Kindergarten Entry Assessment-Administrator survey (see Appendix B). The survey was designed to reflect Pennsylvania's early learning standards and KEA system best practices identified by several state and national organizations (National Association for the Race to the Top-Early Learning Challenge; U.S. Department of Health and Human Services Office of Head Start; Early Childhood Technical Assistance Center; National Academies Press Committee on Developmental Outcomes and Assessments for Young Children; U.S. Department of Education, Institute of Education Sciences, National Center for Education Evaluation and Regional Assistance, Regional Educational Laboratory; Pennsylvania Race to the Top-Early Learning Challenge; Pennsylvania Partnerships for Children [PPC]; Pennsylvania Keys; Office of Developmental Programs and Early Learning; Education Commission of the States; Pennsylvania Department of Education; Collaborative for Academic, 
Social, and Emotional Learning [CASEL]; National Research Council; Education of Young Children [NAEYC] \& National Association of Early Childhood Specialists in State Departments of Education [NAECS/SDE], 2009). A table of best practice recommendations of strategies, purposes, measures, and skill domains within KEA was developed. The survey questions were then developed to reflect these best practices. The online survey was designed to yield a high response rate and low costs of survey administration.

Two questions were added to the administrator survey to obtain information about their teaching experiences in addition to their supervisory experience. The first question in each survey was to obtain consent to participate in the research study. Both surveys contained six multiple-choice items focused on demographic data. Also, six matrix/rating scale items measured the degree to which the programs used KEA for the identified purposes, the skill domains assessed, best practice strategies used, types of assessments used, and types of professional development received.

Twelve open-ended questions included three questions to determine the number of children in the classroom, the number of support staff, and the number of community providers supporting the classroom. Additional open-ended questions allowed participants to indicate any tools used from state or national sources, purposes not indicated on the survey, their biggest challenge, recommendations for improvement, or anything else regarding KEA. There were 27 questions on the teacher version of the survey and 29 questions on the administrator version.

Ten early childhood education/kindergarten teachers and professionals pretested survey questions and professionals to obtain validity and reliability data. Pilot participants were selected by asking colleagues who work in early childhood education at the state and local level to review the survey. Five of the people identified to pilot the survey were familiar with the Pennsylvania 
KEI, Pre-K Early Learning Standards, and best practices in kindergarten assessment and teacher development. They reviewed the survey compared to national best practice recommendations for KEA to determine content validity and face validity. Respondents also provided feedback on the time needed to complete the survey.

\section{Administration Procedures}

Surveys were disseminated via email from several Pennsylvania state education organizations and agencies. The email included (a) an introduction explaining the purpose of the study; (b) benefits to the respondents and others; (c) confidentiality of the data; (d) privacy disclaimer; (e) a description of the procedure for completing the survey; (f) a consent to participate in the study; (g) a link to the Qualtrics survey corresponding to the respondent's role (e.g., teacher, elementary school administrator); (h) an estimate of time needed to complete the survey; (i) incentives for completing the survey; and (j) the researcher's contact information. The link to the survey was available for nine months (September 2018-June, 2019).

Each organization's leadership was contacted by email and asked to share the survey with its members in a manner they deemed appropriate. The Pennsylvania Principals Association posted the survey on its website for four months. The Pennsylvania Association of Intermediate Units disseminated two emails — one for kindergarten teachers and one for elementary school administrators - to all Pennsylvania school districts. The Pennsylvania Office of Child Development and Early Learning (OCDEL) sent out the survey through their KEI newsletter to stakeholders interested in Pennsylvania's KEI topics. Teachers and principals using the KEI are included in that stakeholder group. The survey was shared with colleagues who work with Pennsylvania public elementary school programs. Finally, a postcard with the informed consent letter on one side and a QR code for the teacher survey was distributed at the Pennsylvania 
Positive Behavior Support Network Implementers Forum Conference in May 2019. A \$25 gift card was provided to 25 randomly selected participants upon completing the survey to increase the response rate.

The measures included in the analysis are teacher KEA best practice strategies, purposes of KEA, skills assessed in KEA, and the type of KEA instrument used. Teacher and administrator data for types of professional development are both included. 


\section{Results}

\section{Comprehensive Early Childhood Education/Kindergarten Assessment System}

The first research question addressed in this study was what kindergarten entry assessment practices are used among Kindergarten teachers in Pennsylvania? Types of Kindergarten Entry Assessment Instruments used by Teachers

Table 3 shows the type of assessment instruments used by Pennsylvania kindergarten teachers to conduct kindergarten entry assessments. Kindergarten teachers reported that school/district-required assessment instruments were used the most often, followed by school/district-recommended instruments, teacher-developed assessment instruments, teacherselected, pre-made instruments, commercial-assessment instruments, and state-recommended assessment instruments.

\section{Table 3}

Teacher Rating of Types of Assessment Instruments Used for KEA

\begin{tabular}{lrrr}
\hline & $n$ & $M$ & $S D$ \\
\hline School/District Required & 48 & 4.04 & 1.53 \\
School/District Recommended & 46 & 3.78 & 1.53 \\
Teacher Developed Assessments & 48 & 3.30 & 1.59 \\
Teacher Selected pre-made Assessments & 48 & 3.00 & 1.62 \\
Commercial Assessment Instrument & 46 & 2.52 & 1.63 \\
State Recommended & 48 & 2.07 & 1.54 \\
\hline
\end{tabular}

\section{Best Practice Strategies of Kindergarten Entry Assessments}

Teachers were asked about the degree to which their KEA practices reflected best practice strategies. The best practice strategy recommendations for KEA were gathered from national-and state-early childhood education organizations (Abry et al.,2017; Hatcher et al., 2012; Obradović et al., 2006; Ray \& Smith, 2010). As shown in Table 4, kindergarten teachers 
reported that developmentally appropriate strategies were used the most often, followed by assessments that align with state standards, and linked to curricula for use in instruction; connected to specific and beneficial purposes; align with preschool programs; are culturally responsive; are tied to children's' daily activities; are sensitive to diverse needs; are supported by professional development; measure social-emotional development; include families; measure student-teacher interactions; use multiple formats; and, are collaborative with preschool teachers.

\section{Table 4}

Teacher Rating of Best Practice Strategies Used for KEA

\begin{tabular}{llll}
\hline & $n$ & $M$ & $S D$ \\
\hline Developmentally Appropriate & 47 & 3.45 & 1.49 \\
Aligned with State Standards & 46 & 3.37 & 1.47 \\
Linked to Curricula use for Instruction & 46 & 3.35 & 1.57 \\
Connected to Specific and Beneficial Purposes & 46 & 3.07 & 1.39 \\
Aligned with Preschool Programs & 46 & 2.93 & 1.58 \\
Culturally Responsive & 45 & 2.93 & 1.56 \\
Tied to Children's Daily Activities & 46 & 2.85 & 1.47 \\
Sensitive to Diverse Needs & 46 & 2.74 & 1.36 \\
Supported by Professional Development & 46 & 2.63 & 1.47 \\
Measure Social-Emotional Development & 47 & 2.60 & 1.57 \\
Inclusive of Families & 45 & 2.53 & 1.41 \\
Use Multiple Formats & 46 & 2.17 & 1.36 \\
Collaborative with Preschool Teachers & 46 & 1.89 & 1.20 \\
\hline
\end{tabular}

\section{Purposes for Kindergarten Entry Assessments}

Teachers were asked to rate how frequently they use KEA to align with national best practice standards and Pennsylvania's KEI purposes. The KEI's purposes are to: (a) provide kindergarten teachers a better understanding of children's competencies at kindergarten entry; (b) tailor their curriculum and instruction to children's individual needs; and (c) provide state, 
district, and school leaders with an evidence-supported, vivid snapshot of children's competencies. As shown in Table 5, kindergarten teachers reported that they used KEA for instructional decision-making most often, followed by differentiating instruction, improving overall classroom interventions, determining class placement, grouping children, identifying students in need of additional support, delaying child entry to school, determining eligibility, and determining exposure to adverse childhood experiences.

\section{Table 5}

Teacher Rating of Purposes for KEA

\begin{tabular}{lccc}
\hline & $n$ & $M$ & $S D$ \\
\hline Instructional decision-making & 45 & 2.84 & 1.41 \\
Differentiate instruction & 46 & 2.61 & 1.52 \\
Determine class placements & 46 & 2.59 & 1.48 \\
Group children & 46 & 2.52 & 1.53 \\
Improve overall classroom interventions & 46 & 2.52 & 1.41 \\
Identify children in need of additional support & 46 & 2.35 & 1.37 \\
Determine exposure to adverse childhood experiences & 46 & 1.85 & 1.14 \\
Delay child entry to school & 46 & 1.83 & 1.22 \\
Determine eligibility & 46 & 1.59 & 1.09 \\
\hline
\end{tabular}

\section{Assessment of Holistic Skills}

Teachers were asked about the degree to which their KEAs evaluated skills across the domains of language and literacy development, cognition, and general knowledge (early math and science), approaches toward learning, physical well-being, motor development, and social and emotional development. As shown in Table 6, kindergarten teachers reported that they assessed the print concepts-letter skills most often, followed by counting, naming numbers, shape identification, receptive language, expressive language, data classification and comparisons, print concepts-words, phonemic awareness, conventions of English language, 
measurement skills, fine motor development, understanding positional words, phonics, engagement, attention and persistence, stages of writing, emotional regulation, decision-making and responsible behavior, self-awareness, physical activity, risk-taking, reading literature, stages of play, algebraic concepts, reading informational text, reasoning and problem-solving, task analysis, skills for establishing and maintaining relationships, the writing process, curiosity, text structure, and creativity. 


\section{Table 6}

Teacher Rating of Skill Domains Measured by KEA

\begin{tabular}{|c|c|c|c|}
\hline & $n$ & $M$ & $S D$ \\
\hline Print Concepts-Letters & 46 & 3.74 & 1.45 \\
\hline Counting & 46 & 3.57 & 1.50 \\
\hline Naming Numbers & 46 & 3.48 & 1.55 \\
\hline Identification of Shapes & 46 & 3.28 & 1.64 \\
\hline Receptive Language & 45 & 3.04 & 1.38 \\
\hline Expressive Language & 45 & 2.98 & 1.44 \\
\hline Data Classification and Comparisons & 46 & 2.85 & 1.45 \\
\hline Collaborative Communication & 45 & 2.84 & 1.35 \\
\hline Print Concepts-Words & 45 & 2.8 & 1.59 \\
\hline Phonological Awareness & 46 & 2.78 & 1.63 \\
\hline Conventions of English Language & 45 & 2.73 & 1.29 \\
\hline Measurement skills & 44 & 2.73 & 1.48 \\
\hline Fine Motor Development & 45 & 2.73 & 1.44 \\
\hline Understanding of Positional Words & 45 & 2.69 & 1.52 \\
\hline Phonics & 46 & 2.65 & 1.68 \\
\hline Engagement, Attention, and Persistence & 45 & 2.64 & 1.35 \\
\hline Stages of Writing & 44 & 2.57 & 1.40 \\
\hline Emotional Regulation & 45 & 2.53 & 1.36 \\
\hline Decision-Making and Responsible Behavior & 45 & 2.47 & 1.44 \\
\hline Self-Awareness & 45 & 2.4 & 1.42 \\
\hline Physical Activity & 45 & 2.31 & 1.44 \\
\hline Risk-Taking & 46 & 2.3 & 1.25 \\
\hline Reading Literature & 45 & 2.22 & 1.40 \\
\hline Stages of Play & 46 & 2.17 & 1.31 \\
\hline Algebraic Concepts & 46 & 2.17 & 1.42 \\
\hline Reasoning and Problem-Solving & 45 & 2.16 & 1.09 \\
\hline Reading Informational Text & 45 & 2.16 & 1.33 \\
\hline Task Analysis Skills & 44 & 2.09 & 1.10 \\
\hline Skills to Establish and Maintain Relationships & 44 & 2.09 & 1.31 \\
\hline Curiosity & 46 & 2.07 & 1.14 \\
\hline Text Structure Skills & 44 & 1.98 & 1.23 \\
\hline Creativity & 45 & 1.93 & 1.18 \\
\hline Writing Process & 44 & 1.91 & 1.22 \\
\hline
\end{tabular}

Instructional Coaching to Assist Kindergarten Teachers in Using/Interpreting Assessments

The second research question was what professional development and coaching do kindergarten teachers receive to perform KEAs? 


\section{Teachers}

As shown in Table 7, kindergarten teachers reported most often that they received onetime training delivered off-site in a large group, followed by a multiple-session training series delivered off-site in a large group, multiple-session training series with feedback on homework delivered off-site in a large group, one-time training delivered off-site in a small group, multiplesession training series delivered off-site in a small group, multiple-session training series with feedback on homework delivered off-site in a small group, training with a core team including feedback after practice delivered on-site, training with a core team including real-time coaching on an ongoing basis delivered on-site, self-paced modules with checks for knowledge throughout delivered virtually, self-paced modules without checks for knowledge throughout delivered virtually, live virtual training with an instructor and other participants and remote one-to-one Coaching/ Consultation via Skype/Zoom/Other.

\section{Administrators}

As shown in Table 7, administrators reported their teachers most often received a onetime training delivered off-site in a large group for KEA professional development, followed by training that included feedback after practice with their core team of teachers delivered on-site, multiple-sessions training series with feedback on homework delivered off-site in a large group, multiple-sessions training series with feedback on homework delivered off-site in a small group, one-time training with core team that included real-time coaching on an ongoing basis that was delivered on-site, self-paced modules done virtually with checks for knowledge throughout, selfpaced modules done virtually without checks, multiple-sessions training series delivered off-site in a large group, one-time training delivered off-site in a small group, multiple-sessions training 
series delivered off-site in a small group, live virtual training with other participants, and remote one-to-one coaching or consultation delivered via Skype/Zoom or other virtual platform. 
PA Kindergarten Assessment Practices

Table 7

Rating by Group for Types of Professional Development for KEA

Teachers

Administrators

n $\quad M \quad S D$

n $\quad M \quad S D$

Off-Site Large Group (20+)

One-Time Training

Multiple Sessions

Multiple Sessions w/ Feedback

Off-Site Small Group (11-19)

One-Time Training

Multiple Sessions

Multiple Sessions w/ Feedback

On-Site with Core Team $(<10)$

Including Feedback after Practice

Including Real-time Coaching

Virtual/Online

Self-Paced w/ Checks

Remote one-to-one Coaching
Self-Paced w/ Checks

Live Virtual Training w/ Other Participants
$44 \quad 1.91 \quad 1.41$

$\begin{array}{lll}43 & 1.33 & .81\end{array}$

$\begin{array}{lll}43 & 1.19 & .70\end{array}$

.89
$1.33 \quad .77$

43

$1.12 \quad .39$

43

$1.09 \quad .37$

37

$43 \quad 1.74 \quad 1.05$

42

$1.62 \quad 1.08$ $\begin{array}{lll}20 & 1.05 \quad .22\end{array}$

$\begin{array}{lll}20 & 1.05 \quad .22\end{array}$

$20 \quad 1.20$
$20 \quad 1.20$ .41

$20 \quad 1.35$ 59
43

43

43

43
$1.51 \quad .94$

$1.30 \quad .60$

$1.23 \quad .61$

$1.19 \quad .55$ 


\section{Differences between Teachers and Administrators}

The final research question asked how kindergarten teachers' and administrators' knowledge and views about KEA professional development differ?

Forty-six teachers (2 did not complete the survey) and 20 administrators ( 2 did not complete the survey) completed the survey section on professional development. A t-test comparing teachers and administrators on the types of professional development received by teachers is presented in Table 8 .

Teachers and administrators reporting for their teachers differed significantly on receiving one time-training with their core team, including ongoing coaching delivered on-site, $t(58.09)=-2.20, p=.032$, with teachers reporting receiving one-time training with their core team including coaching more frequently than administrators. Teachers and administrators reporting for their teachers differed significantly on receiving one time-training delivered off-site in a small group, $t(-2.16)=52.83, p=.04$, with teachers reporting receiving one time-training delivered off-site in a small group more frequently than administrators. There was no significant difference between what teachers and administrators reported for the following professional development categories: a one-time training including feedback after practice delivered on-site with their core team, $t(58.73)=-1.91, p=.06$; live virtual training with other participants, $t(61)=$ $-1.70, p=.10$; multiple-sessions training delivered off-site in a large group, $t(59.49)=-1.60, p=$ .12 ; virtual/remote one-to-one coaching, $t(61)=-1.52, p=.13$; one-time training delivered offsite in a large group, $t(62)=-1.31, p=.20$; self-paced modules with checks throughout delivered virtually, $t(61)=-1.25, p=.22$; multiple-session training delivered off-site in a small group, $t(61)=-0.71, p=.48$; multiple-session training with feedback after practice delivered off-site in a small group, $t(61)=0.68, p=.50$; virtual self-paced modules without checks, $t(61)=-0.54, p=$ 
.59 ; and multiple-session training with feedback after practice delivered off-site in a large group, $t(61)=0.07, p=.95$.

\section{Table 8}

Independent Samples t-Test between Teachers and Administrators on Professional Development

\begin{tabular}{|c|c|c|c|}
\hline & $t$ & $d f$ & $p$ \\
\hline Core team training with ongoing coaching (on-site) & -2.20 & 58.09 & $* 0.03$ \\
\hline One-time training (off-site; small group) & -2.16 & 52.88 & $* 0.04$ \\
\hline Core team training including feedback after practice (on-site) & -1.91 & 58.73 & 0.06 \\
\hline Live virtual training with other participants & -1.70 & 61 & 0.10 \\
\hline Multiple-session training (off-site; large group) & -1.60 & 59.49 & 0.12 \\
\hline Virtual/remote one-to-one coaching & -1.52 & 61 & 0.13 \\
\hline One-time training (off-site; large group) & -1.31 & 62 & 0.20 \\
\hline Virtual self-paced modules with checks throughout & -1.25 & 61 & 0.22 \\
\hline Multiple-session training (off-site; small group) & -0.71 & 61 & 0.48 \\
\hline $\begin{array}{l}\text { Multiple-session training with feedback after practice (off- } \\
\text { site; small group) }\end{array}$ & 0.68 & 61 & 0.50 \\
\hline Virtual self-paced modules without checks & -0.54 & 61 & 0.59 \\
\hline $\begin{array}{l}\text { Multiple-session training with feedback after practice (off- } \\
\text { site; large group) }\end{array}$ & 0.07 & 61 & 0.95 \\
\hline
\end{tabular}




\section{Discussion}

Children's transition to school is a critical period that requires schools to use a comprehensive kindergarten entry assessment (KEA) system that uses best practice strategies to benefit children and their families. School staff also need to consider instruments that assess whole-child domains for cognitive and noncognitive skills (Abry et al., 2017; Hatcheret al., 2012; Obradović et al., 2006; Ray \& Smith, 2010). Finally, teachers need to be supported by professional development and coaching to develop competencies for implementing KEAs. These competencies include: (a) knowledge of the subject matter, curriculum, and adaptations; (b) meeting learner needs; (c) mastering education pedagogy and connecting to goals of the curriculum; (d) understanding the education context; and (e) and knowing their strengths and weaknesses as a professional (Pianta et al., 2014). Ongoing training and coaching are necessary to accomplish these competencies (Joyce \& Showers, 2002; Lino, 2014; Schachter, 2015; Stewart, 2014).

This study aimed to understand the KEA practices of kindergarten teachers in Pennsylvania. Kindergarten teachers in Pennsylvania reported assessing cognitive skills more than non-cognitive skills, using data for instructional decision-making for individual children, and overall classroom improvement. Teachers use KEAs to benefit children but receive little or no professional development for KEAs. The study informs future research and practices with KEA systems and how to support school districts in implementing KEA systems.

\section{KEA Practices Among Kindergarten Teachers}

The first question of interest in the study focused on Pennsylvania kindergarten teachers' KEA practices. A survey assessed the purposes, best practice strategies, and child skill domains assessed by teachers. This study is the first to survey kindergarten teachers in Pennsylvania to 
identify the best assessment practices used. Results show a range of best practices being implemented by the teachers.

\section{Assessments to Understand Children's Skills, Knowledge, and Behaviors}

The Pennsylvania Early Learning Standards for Kindergarten and the Pennsylvania Kindergarten Entry Inventory (KEI) outline skill domains to assess the whole child when entering kindergarten. These measures provide teachers with a snapshot of a range of cognitive and noncognitive skills. The teachers' report of assessing cognitive and non-cognitive skills is consistent with previous literature indicating that KEAs children's assess social, cognitive, and emotional skills (Abry et al., 2017; Hatcher et al., 2012; Obradović et al. 2006; Ray \& Smith, 2010). The domain assessed most by kindergarten teachers are cognitive skills. Survey results suggest that kindergarten teachers in Pennsylvania assess the noncognitive, social-emotional skill domain less often than cognitive and academic skills. Teachers' lack of access to socialemotional measures and poor understanding of non-cognitive skills may explain why they do not assess this skill as often as cognitive skills. Previous research has pointed out that the child's cognitive and noncognitive skills provide a strong foundation for learning. Deficits in their social-emotional and non-cognitive skills may prevent young children from succeeding in school (Curby et al., 2015; Denham et al., 2014; Desimone, 2011; Dusenbury et al., 2015; Daily \& Maxwell, 2018; Little et al., 2020).

The survey results show teachers assess students' print concepts—letters, counting, naming numbers, identification of shapes, and receptive language most frequently. The skill domains assessed least often by teachers are the writing process, creativity, text structure skills, curiosity, and skills for establishing and maintaining relationships. These results align with research showing that most individualized, relationship-building activities tend to be least used 
by kindergarten teachers. Differences in practices to ease the transition to school for young children are associated with school characteristics. For example, characteristics of a large, urban school may limit the opportunities for teachers to have personal contacts with families while smaller, rural schools may provide more opportunities to build relationships with families during the transition to school (Boethel, 2004; Domínguez et al., 2010; Diamond, 2010; McDermott et al., 2012). Measuring cognitive skills more than non-cognitive skills could affect the identification of children that need academic and social skills intervention (Pavelski-Pyle, 2002; Diamond, 2010; Walsh, 2005; McDermott et al., 2012; Race to the Top-Early Learning Challenge, 2009; US Department of Health and Human Services, 2010; National Research Council, 2008; Pennsylvania Office of Child Development and Early Learning, 2017). Previous research has found that failure to identify children's non-cognitive skills has costly outcomes, such as grade retainment, need for supplemental and specialized instruction, and academic support through an Individualized Education Plan (IEP) or 504 plan. These children are also at greater risk of suspension or expulsion from school (Bettencourt et al., 2018; Joseph \& Strain, 2003; Zins, Bloodworth, Weissberg \& Walberg, 2004; Webster-Stratton, Reid \& Stoolmiller, 2008).

\section{Kindergarten Assessment Best Practices Strategies}

This study aimed to understand the KEA best practices used by Pennsylvania teachers. These results are the first demonstration of teacher best practices in the Commonwealth. The results show that Pennsylvania kindergarten teachers use developmentally appropriate KEAs that align with Pennsylvania Kindergarten Early Learning Standards. KEAs are linked to the curriculum, instruction, are beneficial for children, align with preschool curricula, and are culturally/linguistically responsive. This finding is consistent with previous literature for 
developmentally appropriate assessments (Gallagher \& Bennet, 2018; Kirova \& Hennig, 2013; NAECS/SDE, 2003). The teachers also used KEAs aligned to state standards, linked to curriculum and instruction (Marope \& Kaga, 2015; OCDEL, 2017; Race to the Top-Early Learning Challenge, 2009; Smylie, 2014; Stewart, 2014), and culturally and linguistically responsive (Reardon \& Portilla, 2016; Chetty et al., 2016).

Collaboration with preschool and including families in the assessment process were strategies used the least by teachers. Collaborating with preschool programs is critical to providing a seamless transition to kindergarten and intervening early for struggling children. Racial and ethnic disparities account for much, if not most, of the achievement gap we see later in primary and secondary school (Bradbury et al., 2015; Grissmer \& Eiseman, 2008; Duncan et al., 2014; Magnuson et al., 2004). If children's needs are not accurately assessed, the instruction may not overcome environmental factors contributing to ethnic, racial, linguistic, and socioeconomic disparities. Further, if there is a disconnect between preschool and kindergarten programs, transition challenges may be amplified for struggling children. These challenges are mostly present for children of color (Aikens et al., 2013; Mulligan et al., 2012; Larson et al., 2015; Reardon \& Portilla, 2016).

The inclusion of families in the assessment process also provides a broader picture of the child's needs. Providing support to families may prevent adverse impacts from traumatic childhood experiences (Faletti et al., 1998; Finkelhor et al., 2009; Finkelhor et al., 2011; Greeson et al., 2013; Prevention Institute, 2014; Burt et al., 2012). The need for family engagement and collaboration with preschool programs highlights the importance of holistic early childhood education from preschool through grade three (Anda et al., 2006; Anda et al., 2010; Bethell et al., 2014; Shonkoff et al., 2012). 
Many families are impacted by community violence that interferes with their children's attainment of critical competencies — cognitive, sensory, muscular, emotional, social, and behavioral. Families' capacities to provide supportive environments for their children may be compromised (Cronholm et al., 2015; Maggi et al., 2010).

Information gathered from families should be obtained as part of the KEA. The instructional strategies and curricula implemented in kindergarten classrooms should align with learning goals identified for children. Family support can address many of the negative environmental factors impacting children's transition to school.

Unfortunately, families are not regularly included in the KEA process. Teachers may not understand why family participation is a critical component of cultural and linguistic responsiveness (Brown et al., 2007). Teachers may not have access to families as much as necessary. Collaboration between community agencies/partners such as United Way, human services agencies, Headstart programs, preschool programs, intermediate units, higher education, and family organizations on a regional (county or community) basis may improve schools' and teachers' access to families. (Berger, 2019; Ginwright, 2018; Kataoka et al., 2018; Kagan \& Gomez, 2012; McConnico et al., 2016). Collaboration can increase early intervention effectiveness and improve the return on investment for local and state stakeholders. Preventative approaches decrease problem behaviors in schools and communities and improve long-term academic outcomes for young children (Domínguez, Vitiello, Maier \& Greenfield, 2010; Marope \& Kaga, 2015; Race to the Top-Early Learning Challenge, 2009; Smylie, 2014; Stewart, 2014). Ongoing support and interconnectedness of educational and social systems provide a robust foundation for supporting children's growth. 
Preschool programs' lack of access to kindergarten programs may decrease KEA systems and preschool practices' alignment. Teachers may not have the time or resources to collaborate with preschool teachers. Teachers may collaborate on an individual classroom or child basis rather than on a systemic basis with other kindergarten teachers, special education or regular education administrators, or the preschool programs that feed into their school district.

\section{KEA Instruments}

Selecting the appropriate type of assessment to assess children's skills is critical (OCDEL, 2017). Kindergarten teachers must select instructional models, methods, and materials that meet learners' needs in their classrooms (Watts-Taffe et al., 2012). Many states use standardized assessment instruments for KEA (Education Commission of the States, 2014), but the present study found that Pennsylvania teachers rarely use standardized assessment instruments, including the KEI. Pennsylvania teachers most often use the instruments required or recommended by their school districts to conduct KEAs. Seventy of 500 school districts in Pennsylvania use the KEI. There is no state requirement for KEA instruments or practices (KEI, 2019). Pennsylvania school districts exercise local control, and school district leadership selects the KEAs that their teachers use (22 Pa. Code $\S 11.14$.$) .$

\section{Purposes of KEA}

The primary purpose of entry assessment is to inform children's instruction at kindergarten entry and improve overall classroom interventions (OCDEL, 2017). The present study results are consistent with these purposes in regards to KEI. Teachers primarily use KEA to make instructional decisions, differentiate instruction, improve overall classroom interventions, and determine a child's class placement. These results are consistent with the previous literature that reports that teachers can use assessment data to make instructional 
decisions about what to teach and how to schedule instructional time (Gullo \& Hughes, 2011; Halle et al., 2011; Pyle \& DeLuca, 2013). Surveyed teachers used KEAs to delay children's entry to school or determine their eligibility infrequently or not at all. However, the research indicates that teachers and administrators should not use KEAs to delay children's entry to school. Decisions about when to enroll children in school are up to families and parents.

Other research has found that delayed entry of one year may have positive for some children. When delayed-entry children enter school, they have higher non-cognitive skills (Muhlenweg et al., 2019), higher self-confidence, and positive risk-taking behavior (Page, Sakar \& Silva-Goncalves, 2019), reduced probability of grade retention (Barua \& Lang, 2008), are less likely to be diagnosed with a learning disability, and more likely to attend a college or university (Hover, 2018). Children withheld from entering school for one year after their same-age peers are less likely to develop behavioral problems and speech impediments. Delayed entry is unrelated to learning disabilities, ADHD, and dyslexia/dyscalculia (Balestra, Eugster \& Liebert, 2019).

Teachers reported that they used KEAs to determine children's exposure to adverse childhood experiences (ACES) infrequently. ACES assessments are not typically administered to children as a condition of kindergarten entry. Mental health clinicians often caution against administering ACES assessments to young children. The questions may trigger traumatic memories in children (Swanberg, 2019; White et al., 2019).

Pennsylvania kindergarten teachers use best practice strategies of using developmentally appropriate and culturally responsive assessments that are done collaboratively with preschool programs, families, are aligned to state learning standards, and are linked to kindergarten curriculum and instruction when using KEAs to assess cognitive and noncognitive skills. 


\section{Professional Development}

Previous studies have demonstrated two vital components of effective KEA practice. The first is professional development to support teachers' use of KEAs. Teachers in the current study reported they received little to no professional development in regards to how to administer, evaluate, and use data gathered from KEAs. They reported that they received only large group one-time training delivered off-site, in most cases. Multiple-sessions training and one-to-one coaching was received least often.

Administrators reported their teachers received little to no professional development for KEAs. The most frequent training offered was one-time large-group training that was delivered off-site. Live virtual training and remote one-to-one coaching were provided least often, according to school administrators. These results were not unexpected. Teachers rarely receive the institutional support they need (Leiber et al., 2009), have limited access to resources, and rarely participate in professional development (Ingersoll, 2014).

\section{Differences Between Teachers and Administrators Reports}

Kindergarten teachers and elementary administrators differed significantly regarding onetime training with the core team and ongoing coaching delivered on-site. Because the teachers and administrators worked in different schools. These results are difficult to interpret, as local school contexts (e.g., policies, staffing) likely impact the needs for, and provision of, professional development for teachers. Thus, it is not surprising that there were differences between the two groups. Teachers' responses indicated they received less professional development than what the administrators reported provided for their teachers. The responding administrators may have provided more professional development opportunities for their teachers than is typical. This study's findings highlight the lack of consistent professional 
development provided to teachers to effectively administer, analyze, and use the resulting data for decision making.

\section{Limitations of the Study}

The present study represents the first attempt to gather information from teachers and administrators in Pennsylvania schools. Of 3,407 public schools, 1,221 elementary schools offer kindergarten programs. Approximately 8,337 kindergarten teachers work in Commonwealth schools. The sample size of 48 teachers is approximately $.5 \%$ of the population. The small sample of teachers is the most significant limitation of the study. Out of 1,221 elementary schools that offer kindergarten programs, only 22 administrators completed the survey, representing approximately .2\% of the Pennsylvania schools' administrator population. Thus, results must be interpreted with caution, given the small sample sizes. Purposeful participant sampling limited the generalization of the results to the larger population of Pennsylvania kindergarten teachers and administrators. This study is the first step to evaluate KEAs in Pennsylvania, and more extensive research could build on these results. The majority of participants in the study were white, non-Hispanic women. The demographic characteristics of kindergarten teachers in Pennsylvania are unknown.

Another limitation is that no observational data were obtained to confirm the survey responses. Thus, the study could not determine if teachers received any professional development for KEAs.

Also, survey responses might reflect social desirability on the part of respondents. A final limitation is that the differences between teachers and administrators in their perspectives on professional development opportunities may have occurred by chance. 


\section{Implications of the Research}

These results of this investigation suggest several theoretical and practical implications. Comprehensive professional development opportunities are needed to increase teacher knowledge and skills for KEAs.

Teacher-coaching models can provide a flexible framework to support teacher professional development for KEA efforts. Many questions remain about whether coaching is best implemented on a small scale with targeted programs tailored to local contexts or if coaching can be taken to scale in a high-quality and cost-effective way (Kraft et al., 2018). Conducting focused needs assessment in kindergarten programs to identify teachers' professional development needs. Professional development programs can then be tailored to meet needs and sustain practices over time. The goal is to build staff capacity within a school district to support an effective KEA system. Kraft et al. (2018) suggest that differences in professional development for assessment administration are due to one or more substantive changes in the coaching model, namely, teacher-to-coach ratios, the total number of weeks of coaching received, turnover of coaches, or shifts in the coaching focus.

Teachers receive little training to assess children's non-cognitive skills, social-emotional skills, and the factors that impact children's well-being (Gibb \& Papoi, 2020; Thomas et al., 2019), such as having experienced adversities or traumatic events. Many teachers feel poorly equipped to support students who have experienced trauma (Kataoka et al., 2018), having received few trauma-related resources for building knowledge, shifting perspectives, and engaging in self-care (Thomas et al., 2019; Gibbs \& Papoi, 2020). Teachers lack knowledge of implementing evidence-based social-emotional learning curriculum that can support children's ability to recognize and manage their emotions and build resilience (Guarino \& Chagnon, 2018; 
LaRocca \& Krachman, 2018). Supporting students in developing strong SEL skills is beneficial to the student and the greater community (Espelage et al., 2020)

It is recommended that a system-wide approach to professional development, evaluation, progress monitoring, and instruction using a multi-tiered system of support be implemented (Maynard et al., 2019; McConnico et al., 2016; Berger, 2019; Boldt, 2020; Chafouleas et al., 2016; Ridgard et al., 2015). This system would integrate all professional development, practices, data, and systems for academics, social-emotional, and behavioral domains.

Teachers and administrators reported that teachers receive little to no professional development for KEAs. Much work needs to be done before a full understanding of the extent of teacher professional development for KEAs in Pennsylvania is realized.

\section{Directions for Future Research}

Much work remains to be done before a full understanding of KEA systems used by teachers in Pennsylvania can be achieved. There are kindergarten programs throughout the state that do not use a KEA. It would be useful to extend the current findings by surveying a larger, more representative sample of teachers and administrators to gather data on their views about selecting KEA instruments and of school districts' decision-making processes. It would also be useful to look at the barriers to implementing KEA best practices when KEAs are administered and the additional assessments used in kindergarten programs for diagnostic or other purposes. One of the most important implications is for the collaboration of teachers in preschools through third grade to align practices, assessments, family engagement, and community partners to ease children's transition to kindergarten. Further research is recommended to identify how barriers to collaboration between kindergarten and preschool teachers can be removed. 
This study raises several questions for future study. What are the most appropriate ways to assess children's exposure to adverse childhood experiences for KEAs? How can school districts and preschool programs partner with community agencies to create a streamlined KEA system that includes families? Further research should be done to identify an effective coaching model that would provide professional development to improve kindergarten readiness preparation in preschools and ease children's transition to elementary schools while engaging families and community partners.

More research on adverse childhood experiences (ACES) in young children across Pennsylvania and documenting its impacts on kindergarten readiness would be recommended to identify potential mitigation efforts. (Bethell et al., 2014; Purewal et al., 2016). These additional studies would be useful to policymakers for early childhood education and human services organizations. Also, OCDEL could use the information to develop programs, supports, collaboration opportunities with medical partners and family organizations.

A future research study could identify the professional development needed to increase kindergarten teachers' and elementary administrators' knowledge of adverse childhood experiences and their impact on children. Also, to increase teachers' and administrators' skills to implement trauma-informed approaches to education and early learning practices. Identifying appropriate forms of screening to assess adverse childhood experiences in young children is essential (Finkelhor, 2018).

\section{Conclusion}

The present study has provided support for the importance of professional development for kindergarten teachers to use KEAs. Comprehensive professional development includes coaching to improve the uses of comprehensive KEA systems. Such professional development 
should include multiple training sessions with feedback after practice and real-time coaching on an ongoing basis to help kindergarten teachers use and interpret KEA outcomes.

If teachers do not have opportunities to participate in professional development and coaching, they are less likely to be effective in their roles. Professional development should be part of the P-3 continuum of care that includes preschool teachers, kindergarten teachers, and P-3 administrators. Professional development programs should include the best practice strategies identified in previous research.

Finally, support needs to be provided to P-3 schools in Pennsylvania to guide the development and implementation of a multitiered system of support for students and teachers, including academics, behavior, and social-emotional learning.

This study has implications for a tiered approach to kindergarten entry assessment and instructional planning for kindergarten teachers. Buy-in for implementing a comprehensive KEA system within a multitiered system of support is needed for P-3 early learning programs across the Commonwealth of Pennsylvania. There are currently no required protocols or practices for KEA in Pennsylvania. Providing professional development and engaging with stakeholders to illustrate the benefits of using the Pennsylvania KEI is vital to expanding KEA uses in Pennsylvania kindergartens. 


\section{References}

Abry, T., Rimm-Kaufman, S., \& Curby, T. (2017). Are all program elements created equal? Relations between specific social and emotional learning components and teacher-student classroom interaction quality. Prevention Science, 18(2), 193-203. https://doi.org/10.1007/s11121-016-0743-3

Ackerman, D. J. (2018a). Comparing the potential utility of kindergarten entry assessments to provide evidence of English learners' knowledge and skills. ETS Research Report Series, 2018(1), 1-26. https://doi.org/10.1002/ets2.12224

Ackerman, D. J. (2018b). Real-world compromises: Policy and practice impacts of kindergarten entry assessment-related validity and reliability challenges. ETS Research Report Series, 2018(1), 1-35. https://doi.org/10.1002/ets2.12201

Ackerman, D. J., \& Lambert, R. (2020). Introduction to the special issue on kindergarten entry assessments: Policies, practices, potential pitfalls, and psychometrics. Journal of Early Education and Development, 31(5), 629-631.

https://doi.org/10.1080/10409289.2020.1769302

Aikens, N., Klein, A. K., Tarullo, L., \& West, J. (2013). Getting ready for kindergarten: Children's progress during Head Start, FACES 2009 report (OPRE Report No. 201321a). U.S. Department of Health and Human Services, Administration for Children and Families, Office of Planning, Research, and Evaluation. https://files.eric.ed.gov/fulltext/ED580354.pdf

Anda, R. F., Butchart, A., Felitti, V. J., \& Brown, D. W. (2010). Building a framework for global surveillance of the public health implications of adverse childhood experiences. American Journal of Preventive Medicine, 39(1), 93-98. 
Anda, R. F., Felitti, V. J., Bremner, J. D., Walker, J. D., Whitfield, C. H., Perry, B. D., Dube, S.R. \& Giles, W. H. (2006). The enduring effects of abuse and related adverse experiences in childhood. European Archives of Psychiatry and Clinical Neuroscience, 256(3), 174-186.

Baker, B. D., Oluwole, J., \& Green, P. C. (2013). The legal consequences of mandating high stakes decisions based on low-quality information: Teacher evaluation in the race-to-thetop era. Education Evaluation and Policy Analysis Archives, 21(5), 1-71.

Balestra, S., Eugster, B., \& Liebert, H. (2019). Summer-born struggle: The effect of school starting age on health, education, and work. Health Economics, 29(5), 591-607. https://doi.org/10.1002/hec.4005

Bassok, D., Latham, S., \& Rorem, A. (2016). Is kindergarten the new first grade? AERA Open, 2(1), 1-31. https://doi.org/10.1177/2332858415616358

Baumgartner, E. M. (2017). Making gains or falling behind? Changes and stability in school readiness. Social Science Research, 64, 277-298.

Berger, E. (2019). Multi-tiered approaches to trauma-informed care in schools: A systematic review. School Mental Health, 11, 660-664.

Bethell, C. D., Newacheck, P., Hawes, E., \& Halfon, N. (2014). Adverse childhood experiences: assessing the impact on health and school engagement and the mitigating role of resilience. Health Affairs, 33(12), 2106-2115.

Bettencourt, A. F., Gross, D., \& Ho, G. (2016). The costly consequences of not being socially and behaviorally ready by kindergarten: Associations with grade retention, receipt of academic support services, and suspensions/expulsions [Paper presentation]. Baltimore Education Research Consortium, Baltimore, MD, United States. 
Bettencourt, A. F., Gross, D., Ho, G., \& Perrin, N. (2018). The costly consequences of not being socially and behaviorally ready to learn by kindergarten in Baltimore city. Journal of Urban Health, 95(1), 36-50.

Boldt, G. (2020). Possibilities and problems in trauma-based and social-emotional learning programs (ED606413). ERIC. https://files.eric.ed.gov/fulltext/ED606413.pdf

Bradbury, B., Corak, M., Waldfogel, J., \& Washbrook, E. (2015). Too many children left behind: The US achievement gap in comparative perspective. Russell Sage Foundation.

Bridgeland, J., Bruce, M., \& Hariharan, A. (2013). The missing piece: A national teacher survey on how social and emotional learning can empower children and transform schools. Civic Enterprises.

Brown, G., Scott-Little, C., Amwake, L., \& Wynn, L. (2007). A review of methods and instruments used in state and local school readiness evaluations (Issues \& Answers Report, REL 2007-No. 004). U.S. Department of Education, Institute of Education Sciences, National Center for Education Evaluation and Regional Assistance, Regional Educational Laboratory Southeast.

Burt, C. H., Simons, R. L., \& Gibbons, F. X. (2012). Racial discrimination, ethnic-racial socialization, and crime: A micro-sociological model of risk and resilience. American Sociological Review, 77(4), 648-677.

Buysse, V., \& Hollingsworth, H. L. (2009). Program quality and early childhood inclusion: Recommendations for professional development. Topics in Early Childhood Special Education, 29(2), 119-128. 
Cappelloni, N. (2011). Kindergarten teachers' perceptions of kindergarten readiness (UMI No. 3415991) [Doctoral dissertation, The University of San Francisco]. ProQuest Dissertations and Theses Global.

Carver-Thomas, D., \& Darling-Hammond, L. (2017). Teacher turnover: Why it matters and what we can do about it. Learning Policy Institute. https://healthyplacesindex.org/wpcontent/uploads/2017/12/2017_learning_policy_inst_teacher_turnover.pdf

Casey, A., \& McWilliam, R. A. (2011). The characteristics and effectiveness of feedback interventions applied in early childhood settings. Topics in Early Childhood Special Education, 31(2), 68-77.

Chafouleas, S. M., Johnson, A. H., Overstreet, S., \& Santos, N. M. (2016). Toward a blueprint for trauma-informed service delivery in schools. School Mental Health: A Multidisciplinary Research and Practice Journal, 8(1), 144-162. https://doi.org/10.1007/s12310-015-9166-8

Chetty, R., Hendren, N., \& Katz, L. F. (2016). The effects of exposure to better neighborhoods on children: New evidence from the moving to opportunity experiment. American Economic Review, 106(4), 855-902.

Children's Defense Fund (2014). The state of America's children: 2014 Report. https://www.childrensdefense.org/wp-content/uploads/2020/02/The-State-Of-AmericasChildren-2020.pdf

Collet, V. S. (2012). The gradual increase of responsibility model: Coaching for teacher change. Literacy Research and Instruction, 51(1), 27-47. https://doi.org/10.1080/19388071.2010.549548 
Collet, V. S. (2015). The gradual increase of responsibility model for coaching teachers: Scaffolds for change. International Journal of Mentoring and Coaching in Education, 4(4), 269-292. https://doi.org/10.1108/IJMCE-06-2015-0017

Connor, C. M. (2017). Commentary on the special issue on instructional coaching models: Common elements of effective coaching models. Theory Into Practice, 56(1), 78-83. https://doi.org/10.1080/00405841.2016.1274575

Connors-Tadros, L. (2014). Information and resources on developing state policy on kindergarten entry assessment (KEA). Center on Enhancing Early Learning Outcomes.

Copple, C., \& Bredekamp, S. (2009). Developmentally appropriate practice in early childhood programs serving children from birth through age 8. National Association for the Education of Young Children.

Cronholm, P. F., Forke, C. M., Wade, R., Bair-Merritt, M. H., Davis, M., Harkins-Schwarz, M., Pachter, L. M., \& Fein, J. A. (2015). Adverse childhood experiences: Expanding the concept of adversity. American Journal of Preventive Medicine, 49(3), 354-361.

Curby, T. W., Brown, C. A., Bassett, H. H., \& Denham, S. A. (2015). Associations between preschoolers' social-emotional competence and preliteracy skills. Infant and Child Development, 24(5), 549-570.

Curran, F. C., Little, M. H., Cohen-Vogel, L., \& Domina, T. (2020). School readiness assessments for class placements and academic sorting in kindergarten. Educational Policy, 34(3), 518-547.

Daily, S., \& Maxwell, K. (2018). Frequently asked questions about kindergarten entry assessments (Issue Brief No. 36). Research Brief Publication. 
Darling-Hammond, L. (2010). Performance counts: Assessment systems that support highquality learning. Council of Chief State School Officers. https://files.eric.ed.gov/fulltext/ED543057.pdf

Darling-Hammond, L. (2014a). Next-generation assessment: Moving beyond the bubble test to support 21st-century learning. Jossey-Bass Publishers.

Darling-Hammond, L. (2014b). One piece of the whole: Teacher evaluation as part of a comprehensive system for teaching and learning. American Educator, 38(1), 4.

Denham, S. A., Bassett, H. H., Zinsser, K., \& Wyatt, T. M. (2014). How preschoolers' socialemotional learning predicts their early school success: Developing theory-promoting, competency-based assessments. Infant and Child Development, 23(4), 426-454.

Denton, C., \& Hasbrouck, J. (2009). A description of instructional coaching and its relationship to consultation. Journal of Educational and Psychological Consultation, 19(2), 150-175.

Department of Education (ED); US Department of Health and Human Services; Commonwealth of Pennsylvania, Governor's Office. (2016). (rep.). Race to the Top-Early Learning Challenge: 2015 Annual Performance Report. Pennsylvania. Retrieved from https://eric.ed.gov/?id=ED583562

Desimone, L. M. (2011). A primer on effective professional development. Phi Delta Kappan, 92(6), 68-71. https://doi.org/10.1177/003172171109200616

Desimone, L. M., \& Pak, K. (2017). Instructional coaching as high-quality professional development. Theory Into Practice, 56(1), 3-12.

Diamond, A. (2010). The evidence base for improving school outcomes by addressing the whole child and by addressing skills and attitudes, not just content. Early Education and Development, 21(5), 780-793. 
Djambazova-Popordanoska, S. (2016). Implications of emotion regulation on young children's emotional wellbeing and educational achievement. Educational Review, 68(4), 497-515.

Domínguez, X., Vitiello, V. E., Maier, M. F., \& Greenfield, D. B. (2010). A longitudinal examination of young children's learning behavior: Child-level and classroom-level predictors of change throughout the preschool year. School Psychology Review, 39(1), 29-47.

Duncan, G. J., \& Murnane, R. J. (2014). Growing income inequality threatens American education. Phi Delta Kappan, 95(6), 8-14.

Duncan, G. J., Magnuson, K., \& Votruba-Drzal, E. (2014). Boosting family income to promote child development. The Future of Children, 99-120.

Dusenbury, L. A., Newman, J. Z., Weissberg, R. P., Goren, P., Domitrovich, C. E., \& Mart, A. K. (2015). The case for preschool through high school state learning standards for SEL. Handbook of Social and Emotional Learning: Research and Practice, 532-547.

Education Commission of the States (2014). 50-state comparison: Kindergarten entrance assessments. Retrieved from http://ecs.force.com/mbdata/mbquestRT?rep=Kq1407 Published March 29, 2017, in Education Week's Special Report: Navigating New Curriculum Choices

Elek, C., \& Page, J. (2019). Critical features of effective coaching for early childhood educators: A review of empirical research literature. Professional Development in Education, 45(4), $567-585$.

Espelage, D. L., El Sheikh, A., Robinson, L. E., Valido, A., Ingram, K. M., Torgal, C., ... \& Nicholson, A. M. (2020). Development of online professional development for School 
Resource Officers: Understanding trauma, social-emotional learning, restorative discipline, and cultural diversity. Journal of Police and Criminal Psychology, 1-15.

Espinosa, L. M., \& García, E. (2012). Developmental assessment of young dual language learners with a focus on kindergarten entry assessments: Implications for state policies. The University of North Carolina, Frank Porter Graham Child Development Institute, Center for Early Care and Education Research-Dual Language Learners. Faletti, V. J., Anda, R. F., Nordenberg, D., Williamson, D. F., Spitz, A. M., \& Edwards, V. (1998). Relationship of childhood abuse and household dysfunction to many of the leading causes of death in adults. American Journal of Preventive Medicine, 14(4), 245258.

Finkelhor, D. (2009). Children's exposure to violence: A comprehensive national survey. DIANE Publishing.

Finkelhor, D., Turner, H., Hamby, S. L., \& Ormrod, R. (2011). Polyvictimization: Children's exposure to multiple types of violence, crime, and abuse. U.S. Department of Justice. https://www.ncjrs.gov/pdffiles1/ojjdp/235504.pdf

Fomby, P., \& Mollborn, S. (2017). Ecological instability and children's classroom behavior in kindergarten. Demography, 54(5), 1627-1651. https://doi.org/10.1007/s13524-017-06022

Friedman-Krauss, A. H., Barnett, W. S., Garver, K. A., Hodges, K. S., Weisenfeld, G. G. \& Gardiner, B. A. (2020). The state of preschool 2019: State preschool yearbook (8th ed.). National Institute for Early Education Research. 
Gallagher, T. L., \& Bennett, S. M. (2018). The six “p” model: Principles of coaching for inclusion coaches. International Journal of Mentoring and Coaching in Education, 7(1), 19-34. https://doi.org/10.1108/IJMCE-03-2017-0018

Gibbs, B., \& Papoi, K. (2020). Threading the needle: On balancing trauma and critical teaching. Problems and Possibilities in Trauma-Based and Social-Emotional Learning Programs, 2020(43), 1-13.

Ginwright, S. (2018). The future of healing: Shifting from trauma-informed care to healing centered engagement. Kinship Cares.

Goldstein, J., \& Flake, J. K. (2016). Towards a framework for the validation of early childhood assessment systems. Educational Assessment, Evaluation, and Accountability, 28(3), 273-293. https://doi.org/10.1007/s11092-015-9231-8

Goodman, R. D., Miller, M. D. \& West-Olatunji, C. A. (2012). Traumatic stress, socioeconomic status, and academic achievement among primary school students. Psychological Trauma: Theory, Research, Practice, and Policy, 4, 252-259.

Grafwallner, R., Taylor, K., deFosset, S., \& Branscome, K. (2015). Insights on readiness: What states are learning from kindergarten entry assessments [Issue Brief]. Early Learning Challenge Technical Assistance Program. https:/elc.grads360.org/services/PDCService.svc/GetPDCDocumentFile?fileId=16184

Greenburg, J. E., \& Winsler, A. (2020). Delayed kindergarten entry among low-income, ethnically diverse children: Prevalence, predictors, and selection patterns. Early Childhood Research Quarterly, 53, 496-506.

Greeson, J. K., Briggs, E. C., Layne, C. M., Belcher, H. M., Ostrowski, S. A., Kim, S., Lee, R. C., Vivrette, R. L., Pynoos, J. A., \& Fairbank, J. A. (2013). Traumatic childhood 
experiences in the 21st century: Broadening and building on the ACE studies with data from the National Child Traumatic Stress Network. Journal of Interpersonal Violence, 29(3), 536-556.

Grissmer, D., \& Eiseman, E. (2008). Can gaps in the quality of early environments and noncognitive skills help explain persisting Black-White achievement gaps? In K. Magnuson \& J. Waldfogel (Eds.), Steady gains and stalled progress: Inequality and the Black-White test score gap (pp. 139-180). Russell Sage Foundation.

Guarino, K., \& Chagnon, E. (2018). Trauma-sensitive schools training package. National Center on Safe Supportive Learning Environments. https://safesupportivelearning.ed.gov/trauma-sensitive-schools-training-package

Gullo, D. F., \& Hughes, K. (2011). Reclaiming kindergarten: Part I. Questions about theory and practice. Early Childhood Education Journal, 38(5), 323-328.

Halle, T., Zaslow, M., Wessel, J., Moodie, S. \& Darling-Churchill, K. (2011). Understanding and choosing assessments and developmental screeners for young children ages 3-5: Profiles of selected measures. U.S. Department of Health and Human Services. https://eclkc.ohs.acf.hhs.gov/child-screening-assessment/article/understanding-choosingassessments-developmental-screeners-young

Hatcher, B., Nuner, J., \& Palsel, J. (2012). Kindergarten readiness and preschools: Teachers' and parents' beliefs within and across programs. Early Childhood Research \& Practice, $14(2), 1-17$.

Hochberg, E., \& Desimone, L. (2010). Professional development in the accountability context: Building capacity to achieve standards. Educational Psychologist, 45(2), 89-106. 
Hooper, S. R., Roberts, J., Sideris, J., Burchinal, M., \& Zeisel, S. (2010). Longitudinal predictors of reading and math trajectories through middle school for African American versus Caucasian students across two samples. Developmental Psychology, 46(5), 1018.

Hover, A. (2018). Making informed decisions about academic redshirting and retention through school and community partnerships. International Journal of Whole Schooling, 14(2), 53-62.

Howard, E. C. (2011). Moving forward with kindergarten readiness assessment efforts: A position paper of the early childhood education state collaborative on assessment and student standards. Council of Chief State School Officers. https://files.eric.ed.gov/fulltext/ED543310.pdf

Hulse, N. (2020). School leaders' response to the increasing population of culturally and linguistically diverse learners [Doctoral dissertation, St. John's University]. St. John's Scholar Theses and Dissertations. https://scholar.stjohns.edu/theses_dissertations Ingersoll, R., Merrill, L., \& Stuckey, D. (2018). The changing face of teaching. Educational Leadership, 75(8), 44.

Jacobson, D. (2016). Building state P-3 systems: Learning from leading states [Policy report]. Center on Enhancing Early Learning Outcomes. http://ceelo.org/wpcontent/uploads/2016/08/ceelo_pdg_P3systems_AligningEarlyEducFINAL.pdf Jones, J., Reidy, M. C., Hargreaves, M., \& Rog, D. (2017). Translating brain science research into community-level change. Academic Pediatrics, 17(7), S24-S25.

Jones, R. J., Woods, S. A., \& Guillaume, Y. R. F. (2016). The effectiveness of workplace coaching: A meta-analysis of learning and performance outcomes from coaching. Journal 
of Occupational and Organizational Psychology, 89(2), 249-277.

https://doi.org/10.1111/joop.12119

Joseph, G. E., \& Strain, P. S. (2003). Comprehensive evidence-based social-emotional curricula for young children: An analysis of efficacious adoption potential. Topics in Early Childhood Special Education, 23(2), 65-76.

Joyce, B., \& Showers, B. (2002). Designing training and peer coaching: Our needs for learning. National College for School Leadership. https://www.unrwa.org/sites/default/files/joyce_and_showers_coaching_as_cpd.pdf

Justice, L. M., Logan, J., Boyd, B., Ligon J., \& Miller S. (2015). Improving children's school readiness via teacher coaching: Can it make a difference? The Ohio State University, College of Education and Human Ecology. https://earlychildhood.ehe.osu.edu/files/2016/04/White_Paper_Coaching_Final_Compres sed.pdf

Kagan, S. L., \& Gomez, R. E. (Eds.). (2015). Early childhood governance: Choices and consequences. Teachers College Press.

Kataoka, S. H., Vona, P., Acuna, A., Jaycox, L., Escudero, P., Rojas, C., Ramirez, E., Langley, A., \& Stein, B. D. (2018). Applying a trauma-informed school systems approach: Examples from school community-academic partnerships. Ethnicity \& disease, 28(Suppl 2), 417-426. https://doi.org/10.18865/ed.28.S2.417

Kauerz, K. (2013). The path to lifelong success begins with P-3. Principal. https://www.naesp.org/sites/default/files/Kauerz_MA13.pdf

Kaushal, N., Magnuson, K., \& Waldfogel, J. (2011). How is family income related to investments in children's learning. In G. J. Duncan \& R. Murnane (Eds.), Whither 
opportunity? Rising inequality, schools, and children's life chances (pp. 187-206).

Russell Sage Foundation.

Keily, T., Evans, A., \& Atchison, B. (2019). Strengthening the early childhood education continuum [Policy brief]. Education Commission of the States. https://www.ecs.org/strengthening-the-early-childhood-education-continuum/

Kirova, A., \& Hennig, K. (2013). Culturally responsive assessment practices: Examples from an intercultural, multilingual early learning program for newcomer children. Power and Education, 5(2), 106-119. https://doi.org/10.2304/power.2013.5.2.106

Kornrich, S., \& Furstenberg, F. (2013). Investing in children: Changes in parental spending on children, 1972-2007. Demography, 50(1), 1-23.

Kraft, M. A., Blazar, D., \& Hogan, D. (2018). The effect of teacher coaching on instruction and achievement: A meta-analysis of the causal evidence. Review of Educational Research, 88(4), 547-588.

Kunter, M., Klusmann, U., Baumert, J., Richter, D., Voss, T., \& Hachfeld, A. (2013). Professional competence of teachers: Effects on instructional quality and student development. Journal of Educational Psychology, 105(3), 805-820.

Kurz, A., Reddy, L. A., \& Glover, T. A. (2017). A multidisciplinary framework of instructional coaching. Theory Into Practice, 56(1), 66-77. https://doi.org/10.1080/00405841.2016.1260404

Landry, S. H., Anthony, J. L., Swank, P. R., \& Monseque-Bailey, P. (2009). Effectiveness of comprehensive professional development for teachers of at-risk preschoolers. Journal of Educational Psychology, 101(2), 448-465. 
Landry, S. H., Swank, P. R., Smith, K. E., Assel, M. A., \& Gunnewig, S. B. (2006). Enhancing early literacy skills for preschool children: Bringing a professional development model to scale. Journal of Learning Disabilities, 39(4), 306-324.

LaRocca, B., \& Krachman, S. B. (2018). A data-informed approach to social-emotional learning: Policy recommendations for state and local leaders [Policy brief]. Transforming Education. https://files.eric.ed.gov/fulltext/ED605368.pdf

Lino, D. (2014). Early childhood teacher education: How to enhance professional development. Journal Plus Education/Educatia Plus, 11(2), 200-209.

Little, M. H., \& Cohen-Vogel, L. (2016). Too much too soon? An analysis of the discourses used by policy advocates in the debate over kindergarten. Education Policy Analysis Archives, 24(106).

Little, M. H., Cohen-Vogel, L., Sadler, J., \& Merrill, B. (2020). Moving kindergarten entry assessments from policy to practice evidence from North Carolina. Early Education and Development, 31(5), 1-20. https://doi.org/10.1080/10409289.2020.1724600

Maggi, S., Irwin, L. J., Siddiqi, A., \& Hertzman, C. (2010). The social determinants of early child development: An overview. Journal Pediatrics Child Health, 46(11), 627-635.

Magnuson, K. A., Meyers, M. K., Ruhm, C. J., \& Waldfogel, J. (2004). Inequality in preschool education and school readiness. American educational research journal, 41(1), 115-157.

Magnuson, K. A., \& Waldfogel, J. (2016). Trends in income-related gaps in enrollment in early childhood education: 1968 to 2013. AERA Open, 2(2).

Marope, P. T. M., \& Kaga, Y. (2015). Investing against evidence: The global state of early childhood care and education. UNESCO. 
Martin, W., Strother, S., Beglau, M., Bates, L., Reitzes, T., \& Culp, K. (2010). Connecting instructional technology professional development to teacher and student outcomes. Journal of Research on Technology in Education, 43(1), 53-74.

Martínez, L. (2016). Teachers' coices on social emotional learning: Identifying the conditions that make implementation possible. International Journal of Emotional Education, 8(2), 6.

Maxwell, K., \& Clifford, R. M. (2004). Research in review: School readiness assessment. Young Children, 59(1), 42-46.

Maynard, B. R., Farina, A., Dell, N. A., \& Kelly, M. S. (2019). Effects of trauma-informed approaches in schools: A systematic review. Campbell Systematic Reviews, 15(1-2).

McConnico, N., Boynton-Jarrett R., Bailey, C., \& Nandi, M. (2016). A framework for trauma-sensitive schools: Infusing trauma-informed practices into early childhood education systems. Zero to Three, 36(5), 36-44.

McDermott, P. A., Rikoon, S. H., Waterman, C., \& Fantuzzo, J. W. (2012). The preschool learning behaviors scale: Dimensionality and external validity in Head Start. School Psychology Review, 41(1), 66-81.

Moody, M. S. (2019). If instructional coaching really works, why isn't it working? Educational Leadership, 77(3), 30-35.

Mühlenweg, A., Blomeyer, D., Stichnoth, H., \& Laucht, M. (2019). Effects of age at school entry (ASE) on the development of non-cognitive skills: Evidence from psychometric data. Economics of Education Review, 31(3), 68-76.

Mulligan, G. M., Hastedt, S., \& McCarroll, J. C. (2012). First-time kindergartners in 2010-11: First findings from the kindergarten rounds of the early childhood longitudinal study, 
kindergarten class of 2010-11 (ED533795). ERIC.

https://files.eric.ed.gov/fulltext/ED533795.pdf

National Associations for the Education of Young Children \& The National Association of Early Childhood Specialists in State Departments of Education. (Year). Name of source. http://www.naeyc.org

National Association for the Education of Young Children (NAEYC) (2009). Where we stand on assessing young English Language Learners.

https://rpm.fpg.unc.edu/sites/rpm.fpg.unc.edu/files/resources/NAEYC-WWSEnglishLanguageLearners.pdf

National Association for the Education of Young Children \& The National Association of Early Childhood Specialists in State Departments of Education. (2003). Early childhood curriculum, assessment, and program evaluation: Building an effective, accountable system in programs for children birth through age 8. NAEYC and NAECS/SDE. http://www.naeyc.org/files/naeyc/file/positions/pscape.pdf

National Center for Education Statistics. (n.d.). CCD Public school data 2015-2016, 2016-2017 school years. U.S. Department of Education.

National Research Council of the National Academies (2008). Early childhood assessment: Why, what, and how (C. E. Snow \& S. B. van Hemel, Eds.). The National Academies Press. https://doi.org/10.17226/12446

Scott-Little, C., \& Niemeyer, J. (2001). Assessing kindergarten children: A compendium of assessment instruments. In Washington, DC: Office of Educational Research and Improvement. Retrieved form https://castl. duq. edu/Conferences/Library03/PDF/Dat_Driv_Dec/Niemeyer_J.pdf 
Nuttall, J., Kostogriz, A., Jones, M., \& Martin, J. (Eds.). (2017). Teacher education policy and practice: Evidence of impact, impact of evidence. Springer. https://doi.org/10.1007/978$981-10-4133-4$

Obradović, J., van Dulmen, M. H. M., Yates, T. M., Carlson, E. A., \& Egeland, B. (2006). Developmental assessment of competence from early childhood to middle adolescence. Journal of Adolescence, 29(6), 857-889. https://doi.org/10.1016/j.adolescence.2006.04.009

Office of Child Development and Early Learning (OCDEL)(2017). Program reach and risk assessment, State fiscal year 2015-16, April 2017. Pennsylvania Office of Child Development and Early Learning, Commonwealth of Pennsylvania Department of Education and Department of Human Services, Harrisburg, PA. http://www.pakeys.org/uploadedContent/Docs/Reach\%20and\%20Risk/Reach\%20and\%2 0Risk\%202015-16\%20FINAL\%2004032017.pdf

Office of Head Start (2011). The Head Start child development and early learning framework. U.S. Department of Health and Human Services. https://www.acf.hhs.gov/ohs/resource/hs-child-development-early-learning-framework Pagani, L. S., \& Fitzpatrick, C. (2014). Children's school readiness: Implications for eliminating future disparities in health and education. Health Education \& Behavior, 41(1), 25-33. https://doi.org/10.1177/1090198113478818

Pavelski-Pyle, R. (2002). Best practices in assessing kindergarten readiness. The California School Psychologist, 7, 63-73. 
Pennsylvania Partnerships for Children. (2014). A smart choice for a solid start: The case for pre-k in $P A$. Pennsylvania Partnerships for Children. http://www.prekforpa.org/wpcontent/uploads/2014/02/The-Case-for-Pre-k-in-PA-Feb.-2014.pdf

Pennsylvania Race to the Top-Early Learning Challenge (2015). https://files.eric.ed.gov/fulltext/ED583562.pdf

Pianta, R. C., DeCoster, J., Cabell, S., Burchinal, M., Hamre, B. K., Downer, J., LoCasaleCrouch, J., Williford, A., Howes, C. (2014). Dose-response relations between preschool teachers' exposure to components of professional development and increases in quality of their interactions with children. Early Childhood Research Quarterly, 29(4), 499-508.

Prevention Institute. (2014, October). Making connections for mental health and wellbeing among men and boys in the U.S. https://www.preventioninstitute.org/publications/making-connections-mental-health-andwellbeing-among-men-and-boys-us

Pritzker, J. B., Bradach, J. L., \& Kaufmann, K. (2015). Achieving kindergarten readiness for all our children: A funder's guide to early childhood development from birth to five (ED567744). ERIC. https://files.eric.ed.gov/fulltext/ED567744.pdf

Pyle, A., \& DeLuca, C. (2013). Assessment in the kindergarten classroom: An empirical study of teachers' assessment approaches. Early Childhood Education Journal, 41(5), 373-380. https://doi.org/10.1007/s10643-012-0573-2

Ray, K., \& Smith, M. C. (2010). The kindergarten child: What teachers and administrators need to know to promote academic success in all children. Early Childhood Education Journal, 38(1), 5-18. 
Reardon, S. F., \& Portilla, X. A. (2016). Recent trends in income, racial, and ethnic school readiness gaps at kindergarten entry. Aera Open, 2(3).

Regenstein, E., Connors, M., Romero-Jurado, R. I. O., \& Weiner, J. (2017). Uses and misuses of kindergarten readiness assessment results. Ounce Policy Conversations, 6(11), 1-48.

Regenstein, E., Romero-Jurado, R., Cohen, J., \& Segal, A. (2014). Changing the metrics of turnaround to encourage early learning strategies [Policy brief]. Mass Insight Education. https://ffyf.org/wp-content/uploads/2014/10/ounce-of-prevention-metrics-of-earlylearning-2014.pdf

Repko-Erwin, M. E. (2017). Was kindergarten left behind?: Examining U.S. kindergarten as the new first grade in the wake of no child left behind. Global Education Review, 4(2), 5874.

Ridgard, T. J., Laracy, S. D., DuPaul, G. J., Shapiro, E. S., \& Power, T. J. (2015). Traumainformed care in schools: A social justice imperative. Communique, 44(2), 14-15.

Rush, D., Sheldon, M., \& Hanft, B. (2003). Coaching families and colleagues: A process for collaboration in natural settings. Infants \& Young Children, 16(1), 33-47.

Saracho, O. N. (Ed.). (2015). Contemporary perspectives on research in assessment and evaluation in early childhood education. Information Age Publishing.

Schachter, R. E. (2015). An analytic study of the professional development research in early childhood education. Early Education \& Development, 26(8), 1057-1085. https://doi.org/10.1080/10409289.2015.1009335

Schachter, R. E., Flynn, E. E., Napoli, A. R., \& Piasta, S. B. (2020). Teachers’ perspectives on year two implementation of a kindergarten readiness assessment. Early Education and Development, 31(5), 778-795. 
Schachter, R. E., Gerde, H. K., \& Hatton-Bowers, H. (2019). Guidelines for selecting professional development for early childhood teachers. Early Childhood Education Journal, 47(4), 395-408.

Shonkoff, J. P., Garner, A. S., Siegel, B. S., Dobbins, M. I., Earls, M. F., McGuinn, L., Pascoe, J., Wood, D. L., Committee on Psychosocial Aspects of Child and Family Health, \& Committee on Early Childhood, Adoption, and Dependent Care. (2012). The lifelong effects of early childhood adversity and toxic stress. Pediatrics, 129(1), e232-e246.

Smylie, M. (2014). Teacher evaluation and the problem of professional development. MidWestern Educational Researcher, 26(2), 97-111.

Snow, K. (2011, January). Developing kindergarten readiness and other large-scale assessment systems: Necessary considerations in the assessment of young children. The Center for Applied Research at the National Association for the Education of Young Children (NAEYC). https://www.buildinitiative.org/The-Issues/Diversity-Equity/Toolkit/ToolkitResource-List/View-Toolkit/ArticleId/189/Developing-Kindergarten-Readiness-andOther-Large-Scale-Assessment-Systems-Necessary-Considerations

Son, S. H. C., \& Peterson, M. F. (2017). Marital status, home environments, and family strain: complex effects on preschool children's school readiness skills. Infant and Child Development, 26(2), 1-26. https://doi.org/10.1002/icd.1967

Southwest Educational Development Laboratory (2011). Meeting the needs of diverse learners. https://sedl.org/txcc/resources/briefs/number7/

Stewart, C. (2014). Transforming professional development to professional learning. Journal of Adult Education, 43(1), 28-33. 
Swanberg, S. (2019). ABCs of berg: Adversity and buffers of adversity in preschool children (Publication No. 13881633) [Doctoral dissertation, Tulane University School of Science and Engineering]. ProQuest Dissertations and Theses Global.

Tan, T. X., Wang, Y., \& Ruggerio, A. D. (2017). Childhood adversity and children's academic functioning: roles of parenting stress and neighborhood support. Journal of Child and Family Studies, 26(10), 2742-2752. https://doi.org/10.1007/s10826-017-0775-8

Teemant, A., Wink, J., \& Tyra, S. (2011). Effects of coaching on teacher use of sociocultural instructional practices. Teaching and Teacher Education, 27(4), 683-693. https://doi.org/10.1016/j.tate.2010.11.006

Texas Comprehensive Center at SEDL (2012). Meeting the needs of diverse learners. https://sedl.org/txcc/resources/briefs/number7/

Thomas, M. S., Crosby, S., \& Vanderhaar, J. (2019). Trauma-informed practices in schools across two decades: An interdisciplinary review of research. Review of Research in Education, 43(1), 422-452.

U.S. Department of Education. (2009). Race to the top-early learning challenge executive summary. https://www2.ed.gov/programs/racetothetop-earlylearningchallenge/execsumm.pdf

U.S. Department of Education. (2014). Pennsylvania system of school assessment. Pennsylvania Department of Education. http://www.education.pa.gov/K12/Assessment\%20and\%20Accountability/PSSA/Pages/default.aspx Van der Kolk, B. (2014). The body keeps the score: Mind, brain, and body in the transformation of trauma. Penguin UK. 
Walker, S. P., Wachs, T. D., Grantham-McGregor, S., Black, M. M., Nelson, C. A., Huffman, S. L., Baker-Henningham, H., Chang, S. M., Hamadani, J. D., Lozoff, B., \& Gardner, J. M. M. (2011). Inequality in early childhood: Risk and protective factors for early child development. The Lancet, 378(9799), 1325-1338.

Walsh, C. B. (2005). School readiness indicators: A tool to advocate for the whole child. Advocacy brief(ED491076). ERIC. https://eric.ed.gov/?id=ED491076

Wang, S. (2017). “Teacher centered coaching": An instructional coaching model. Mid-Western Educational Researcher, 29(1), 20-39.

Wanless, S. B., Patton, C. L., Rimm-Kaufman, S. E., \& Deutsch, N. L. (2013). Setting-level influences on implementation of the responsive classroom approach. Prevention Science, 14(1), 40-51.

Wanless, S. B., Rimm-Kaufman, S., Abry, T., Larsen, R., \& Patton, C. (2015). Engagement in training as a mechanism to understanding fidelity of implementation of the responsive classroom approach. Prevention Science, 16(8), 1107-1116. https://doi.org/10.1007/s11121-014-0519-6

Wat, A. (2012). Governor's role in aligning early education and K-12 reforms: Challenges, opportunities, and benefits for children (ED537362). ERIC. https://files.eric.ed.gov/fulltext/ED537362.pdf

Watts-Taffe, S., Laster, B., Broach, L., Marinak, B., Connor, C., \& Walker-Dalhouse, D. (2012). Differentiated instruction: Making informed teacher decisions. The Reading Teacher, 66(4), 303-314. https://doi.org/10.1002/TRTR.01126

Webster-Stratton, C., Reid, M. J., \& Stoolmiller, M. (2008). Preventing conduct problems and improving school readiness: Evaluation of the Incredible Years Teacher and Child 
Training programs in high-risk schools. Journal of Child Psychology \& Psychiatry, 49(5), 471-488. https://doi.org/10.1111/j.1469-7610.2007.01861.x

Weisenfeld, G. G. (2017a). Assessment tools used in kindergarten entry assessments (CEELO FastFact). Center on Enhancing Early Learning Outcomes.

Weisenfeld, G. G. (2017b). Implementing a kindergarten entry assessment (KEA) system (CEELO FastFact). Center on Enhancing Early Learning Outcomes.

White, S., Edwards, R., Gillies, V., \& Wastell, D. (2019). All the ACEs: A chaotic concept for family policy and decision-making? Social Policy and Society, 18(3), 457466.

Yoder, N. (2014). Teaching the whole child: Instructional practices that support socialemotional learning in three teacher evaluation frameworks [Issue brief]. Center on Great Teachers and Leaders. https://gtlcenter.org/sites/default/files/TeachingtheWholeChild.pdf

Zins, J., Bloodworth, M., Weissberg, R., \& Walberg, H. (2004). The scientific base linking social and emotional learning to school success. In J. Zins, R. Weissberg, M. Wang, \& H. J. Walberg (Eds.), Building academic success on social and emotional learning: What does the research say? (pp. 1-22). Teachers College Press. 